
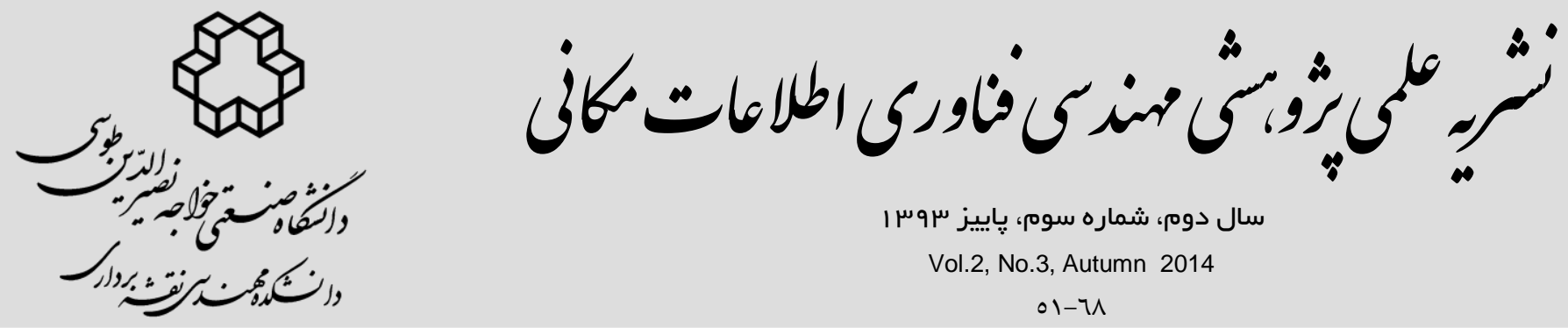

سال دوم، شماره سوم، ياييز سوس 1 س

Vol.2, No.3, Autumn 2014

$01-71$

مطالعه و بازيابى كاركردهاى شهرى در يايغاههاى داده مكانى بر اساس تحليلهاى

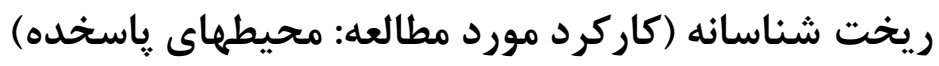

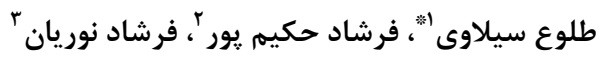

ا - دانشجوى دكترى سيستمهاى اطلاعات مكانى، دانشكده مهندسى نقشهبر داردارى و واطلاعات مكانى دانشعاه تهران

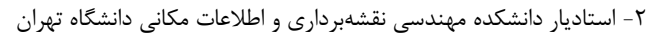

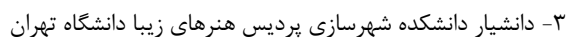

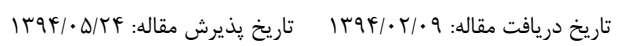

جكيده

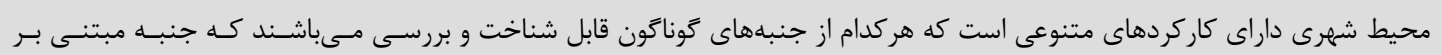

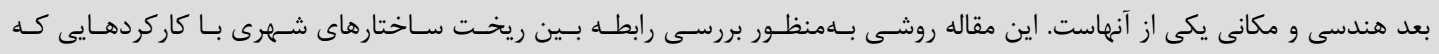

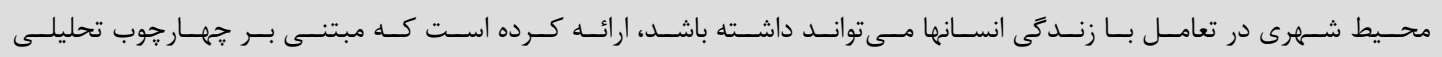

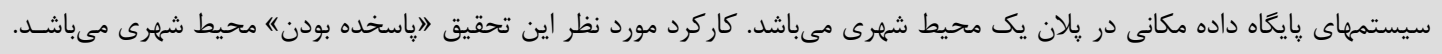

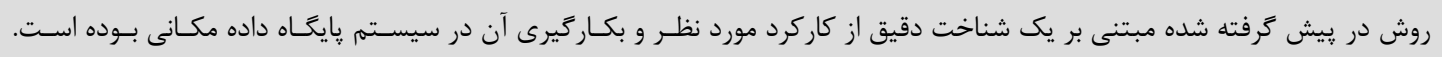

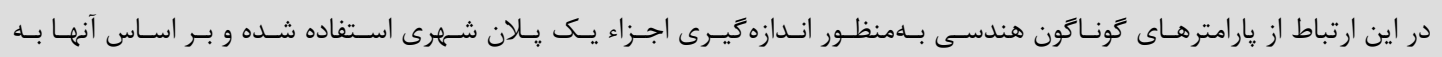

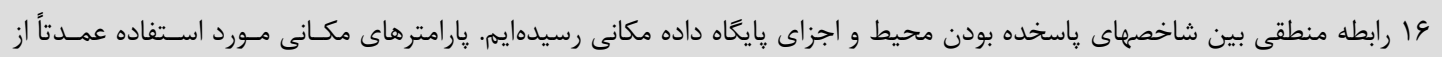

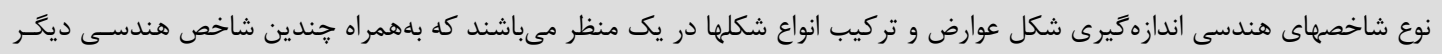

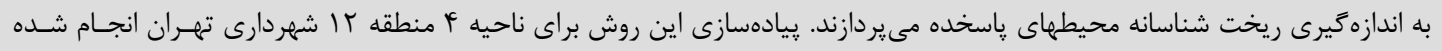

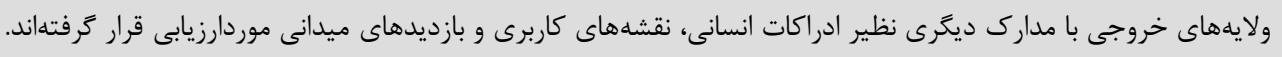

كليدوازهها: پايخاههاى داده مكانى، ريختشناسى شهر، محيطهاى پاسخده، اندازهكيرى منظر.

"نويسنده مكاتبه كننده : خيابان كاركر شمالى (اميرآباد)، يرديس دانشكدهاى فنى دانشًاه تهران، دانشكده مهندسى نقشهبردارى و اطلاعات مكانى. 
بكار مىرود. در اينجا كه ادراكهـا بـا اطلاعـات مكـانى

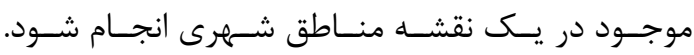
بر اين اساس هدف تحقيق حاضـر تحليـل سـاختارها و

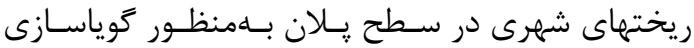

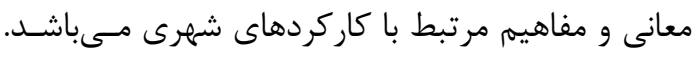
سطح پِلان يعنى يك نقشه ساده از محيط شهرى كـهـ

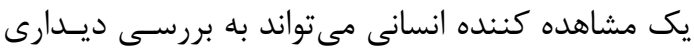

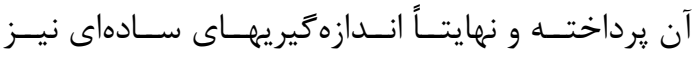
داشته باشد. קنين نقشهاى اكر در قالب يك پايكاه داده

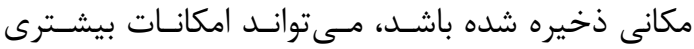
بهمنظور مطالعـات ريخـتشناسـانه در اختيـار بحـــارد.

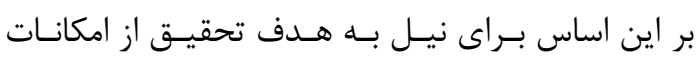

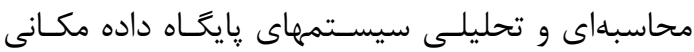

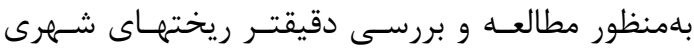

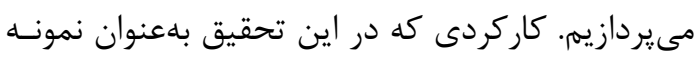

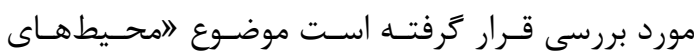
ياسخده" مىباشد كه توسط بنتلى و همكـاران بـراى

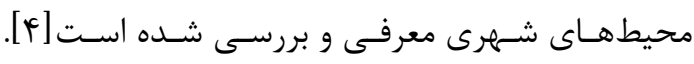

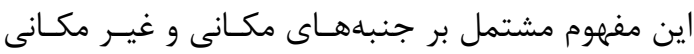

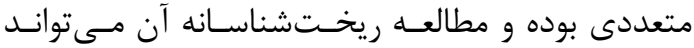
به سؤال اين تحقيق كه سنجش كارايى پايیغاههاى داده

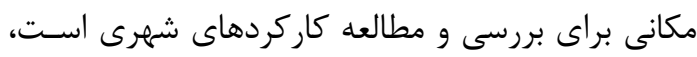

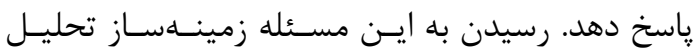

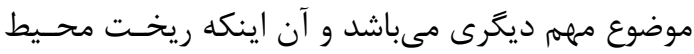

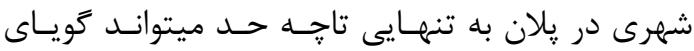

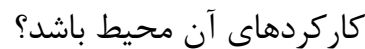

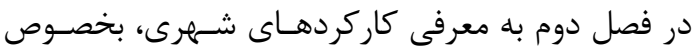
كاركرد مورد نظر اين مقاله كه پاسخدهى محيط شرى شهرى

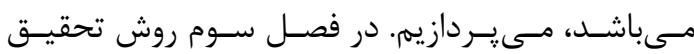

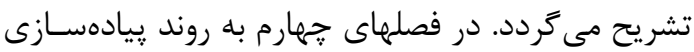

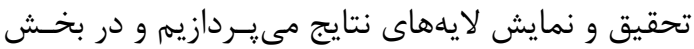

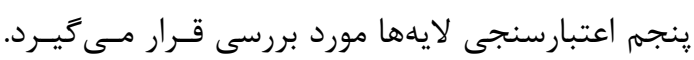
بحث نهايى و يیشنهادات ادامه كار نيز در فصـل ششهم ارائه شده است.
- 1- - 1قدمه

كارشناسان مسائل شهرى سعى داشتهاند كه شـهرها راندا به دو نوع "طراحى شده" و "رشديافته) تقسيم نمايند.

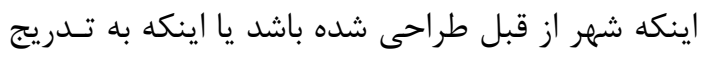

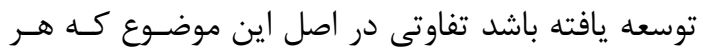

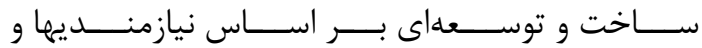

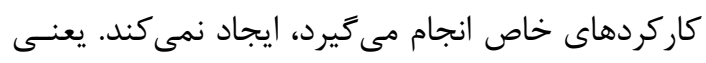

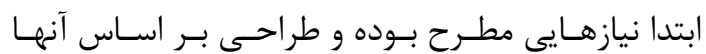

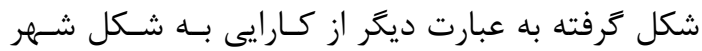
رسيدن [1] . بررسى علمى رابطه بـين شـكل و و كـاركرد

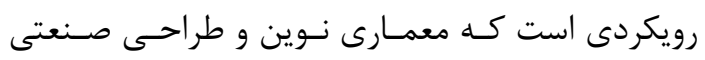

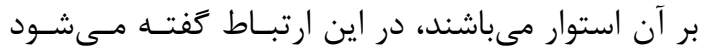

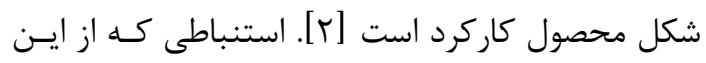

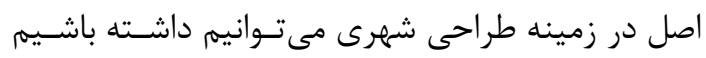

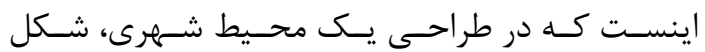

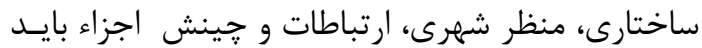

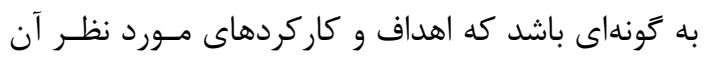
شهر تأمين گردد. بر اساس همين اصل است كه شهرها

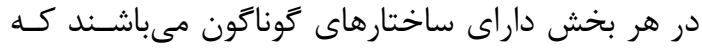

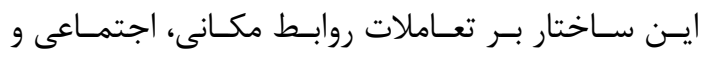

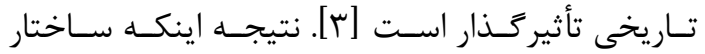

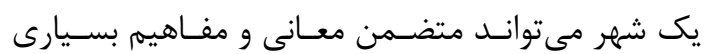

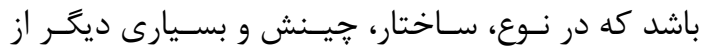

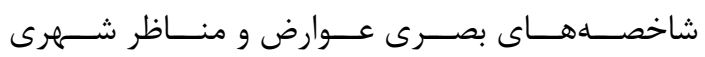

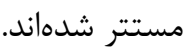
موضوع ايـن تحقيـق درك و بازيـابى جنـين مفــاهيمى

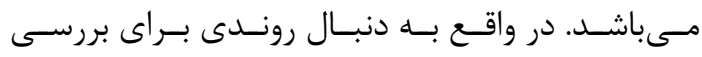
شاخصهاى كاركردى شهر بر اساس ريخت سـاختارهاى

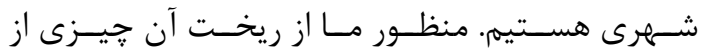

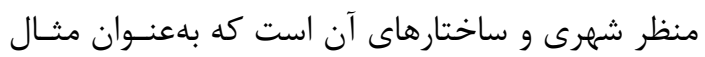

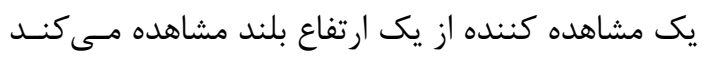

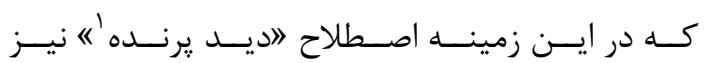

1 Bird's eye view 


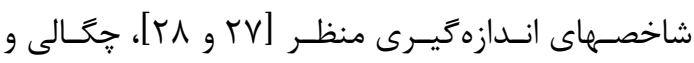

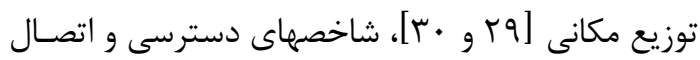

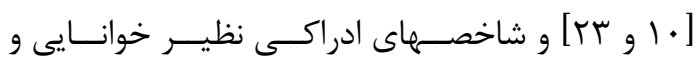
تصوريذيرى [اس]].

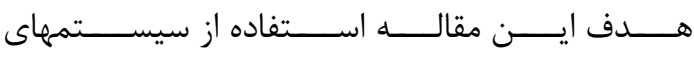

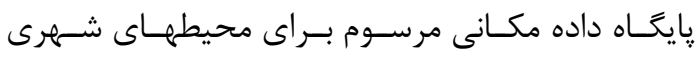

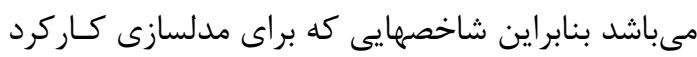

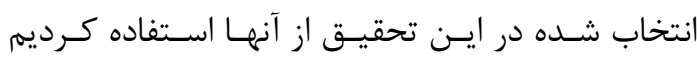

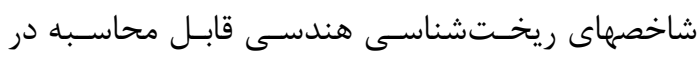
اين سيستمها مىباشند. بر اين اساس شاخصهايى نظيـر

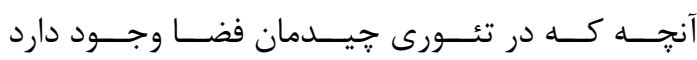

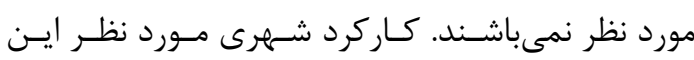
تحقيق مفهوم "محيطهاى ياسخده" مىباشد كه توسط

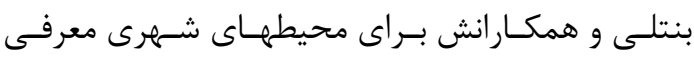

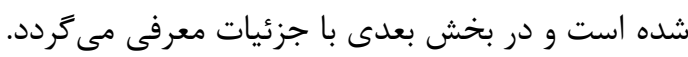

\section{ب- ب- روششناسى تحقيق}

بر اساس هدف و سؤالات تحقيق رويكرد و روش اجرايى روسي اين تحقيق مشتمل بر موارد زير مىباشد الشئ

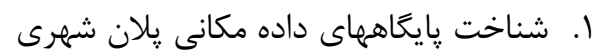

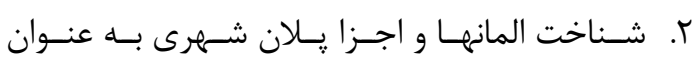
موجوديتهاى پايخاه داده مكانى קلان شهرى

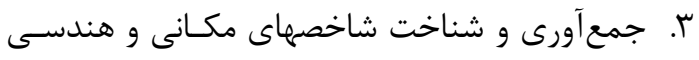

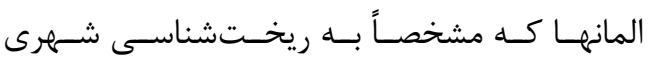

$$
\text { مى ميردازند. }
$$

f. . محاسبه شاخصهاى هندسى در بستر سيستم קايگًاه

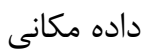

ه. تحليل يارامترى و شناخت كامل كاركرد مورد نظــ كه پاسخدهى محيط شهرى مى باشد.

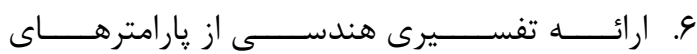
محيطهاى ياسخده به منظور صـريحسـازى آنهـا در

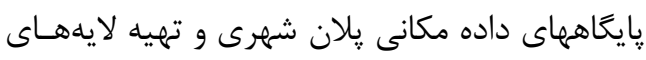

خروجى

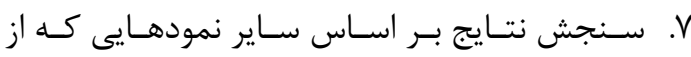
يارامترهاى محيطهاى ياسخده در دسترس هستند.

\section{r- كاركردهاى محيط شهرى}

كاركرد عبارتست از خاصيتى يا مجموعـه خواصى كـهـ

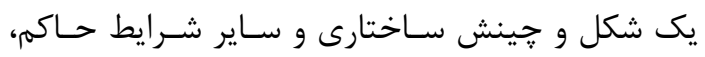

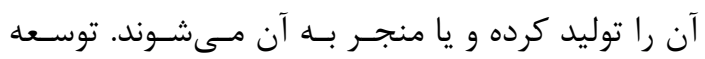

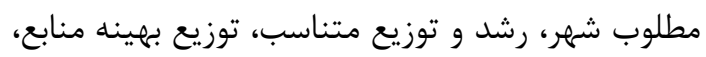

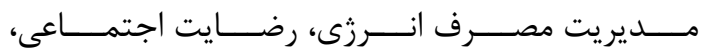

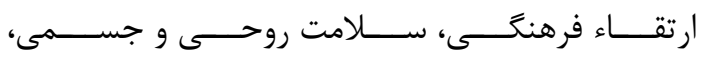

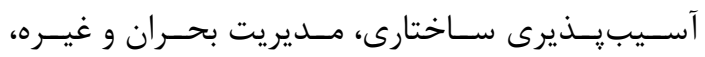
از كاركردهاى مههم و مورد بحـث در رابطـهـ بـا سـازمان

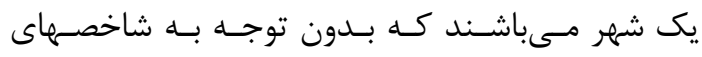

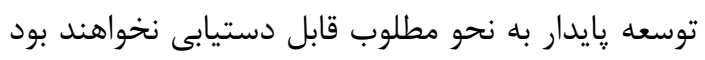
$[1 \cdot-\omega]$

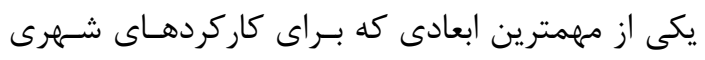

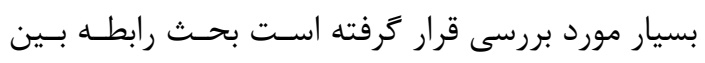
كاركردها با فرم و ريخت محيط شهرى است كه كر كاركرد

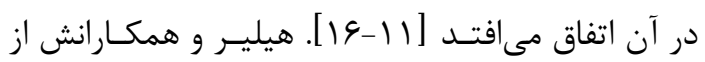

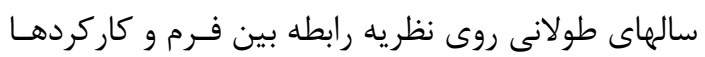

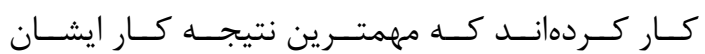

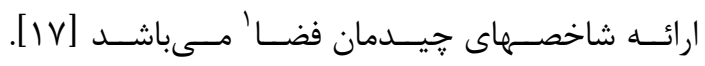

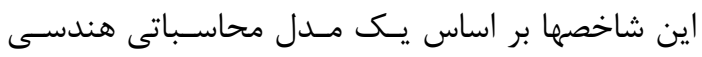

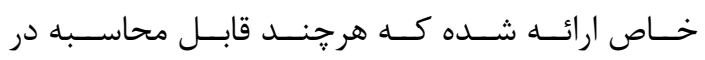
سيستمهاى پإيخاه داده مكانى مى باشد تفاوتهاى اساسى إسى با مدلسازيهاى مكـانى مرسـوم در ايـن سيسـتمها دارد

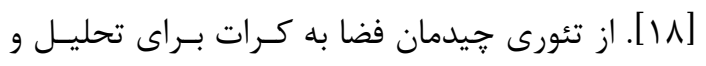

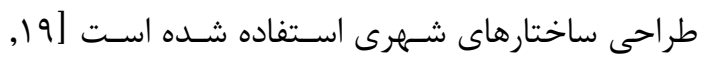

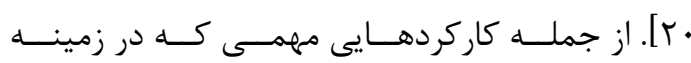

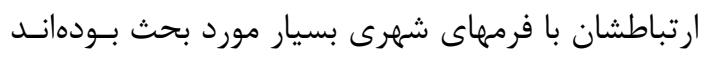

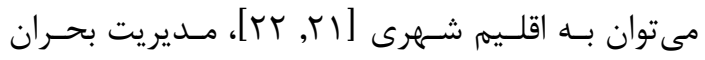

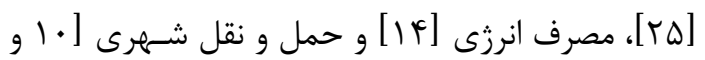

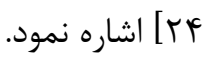
شاخصهاى هندسى كه در اين تحقيقات مـورد اسـتفاده

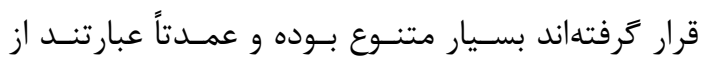

1 Space syntax 


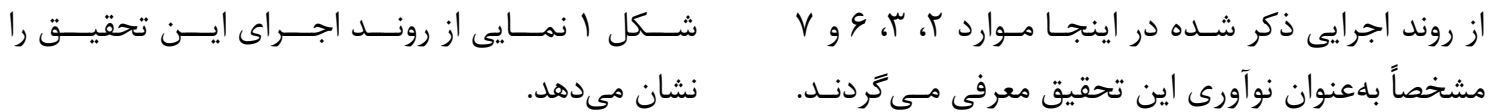

شئاخت مفهوم محيطهاي ياسخده

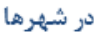

بررسى شاخصهاى ياسخدهي

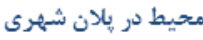

شكل ا: روند اجرايى تحقيق

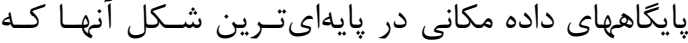

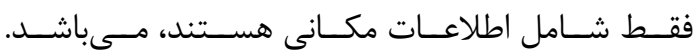

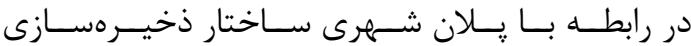
موجوديتهاى مكانى در پِايخاههاى داده مربوط بــهـ آنهـا،

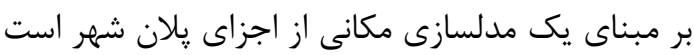

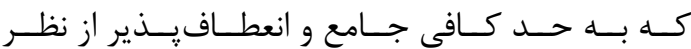

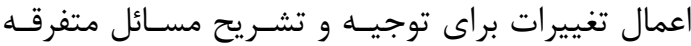

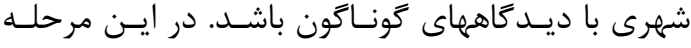

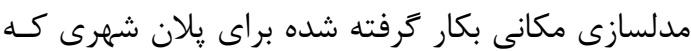

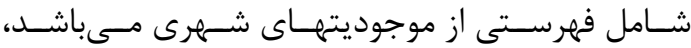
معرفى مى تردد. در اين زمينه لينج درك شهر توسط انسانها را بر اساس

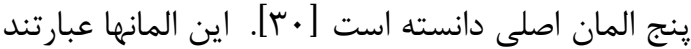

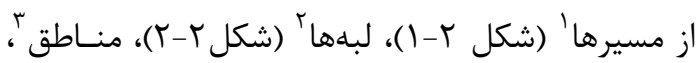

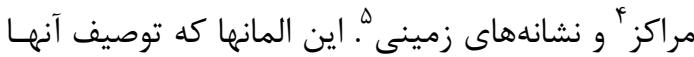

1 Paths

2 Edges

3 Districts

4 Nodes

5 Landmarks
ץ-1- يايخاه داده مكانى براى محيطهاى شهرى نياز به نكهمدارى و بازيابى دادههاى مرتبط با بعـد مكـان منجر به توسعه پايكاههاى داده به نوعى شده اسـت كـهـ

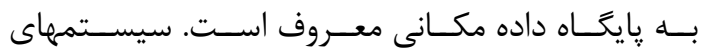

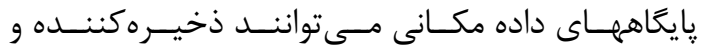
تحليل كننده اطلاعات موقعيت مكانى و ساير اطلاعـات

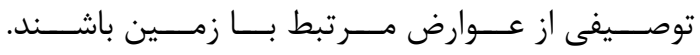

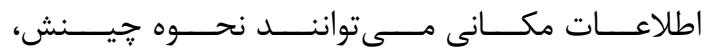

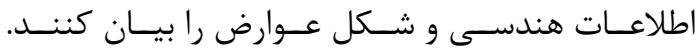

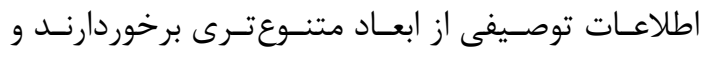

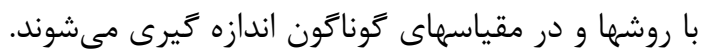

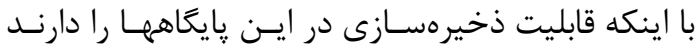
ولى به دليل اينكه به هرحال از ملحقــات ايسن بايكاهيها

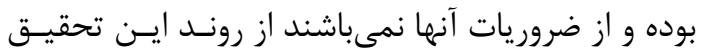
كنار كذاشته مىشوند. از طرف ديخر هرجند كه افزودن

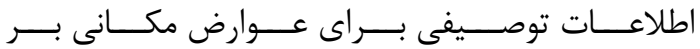

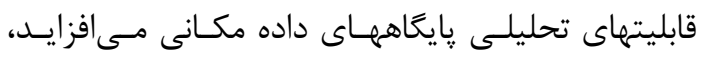

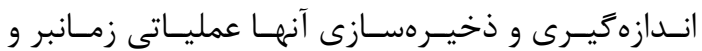
هزينهبر است. لذا جالش اصلى اين تحقيـق اسـتفاده از 


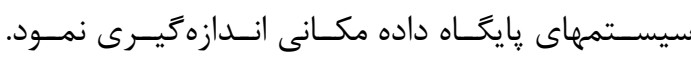

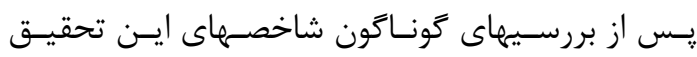

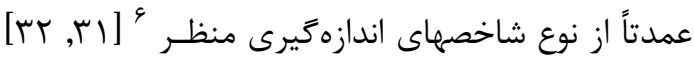

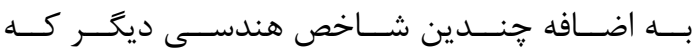

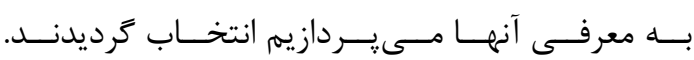

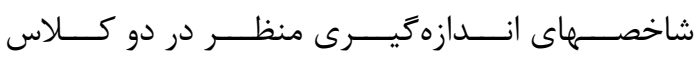

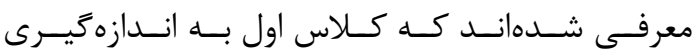

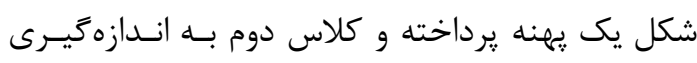

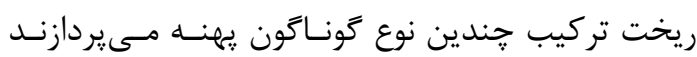

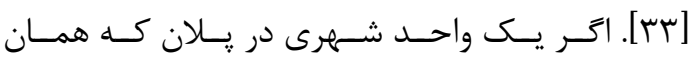

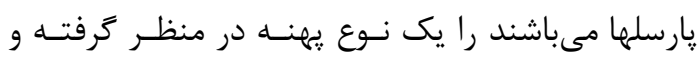
يلان و بلوك، محسـدوده شـهرى و منطقـهـ را بـه عنــوان

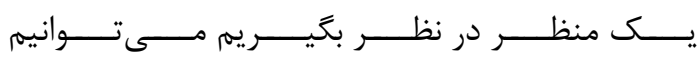

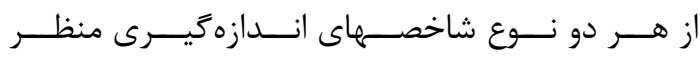

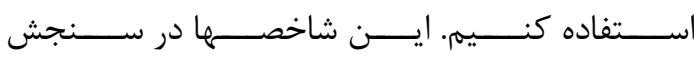

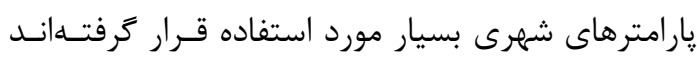

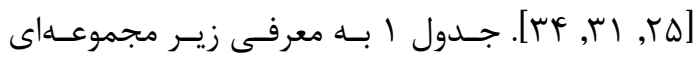

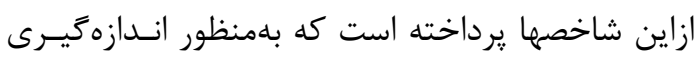

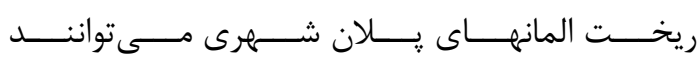

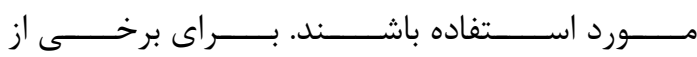

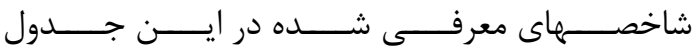

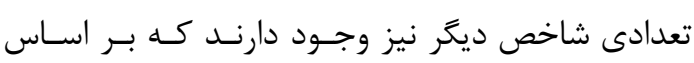

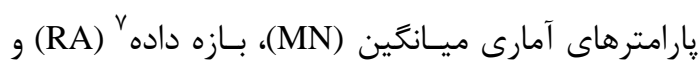

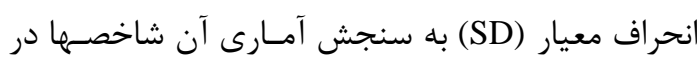

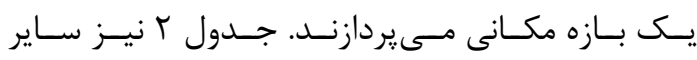
شاخصهاى هندسى قابل بكاركيرى براى المانهاى يـلان محيط شهرى را نشان مى دهد.

6 Landscape Metrics

7 Range
به كرات در متون تخصصى شهرسازى آورده شده است،

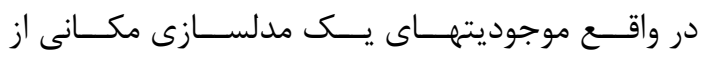

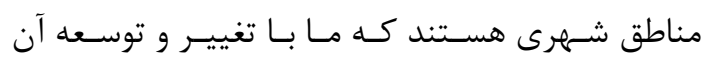

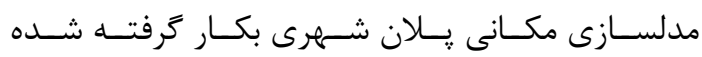

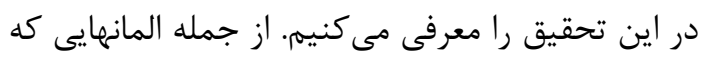

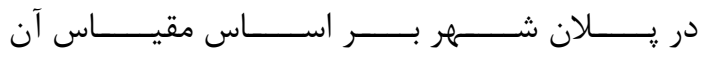

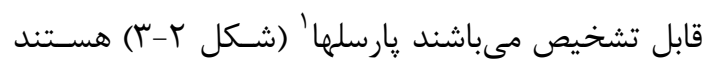

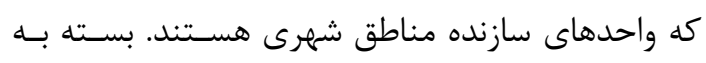

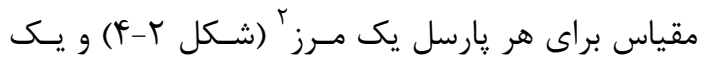

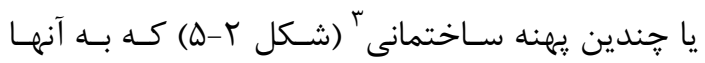

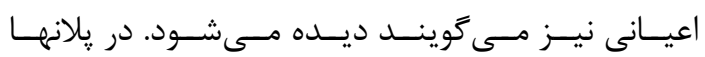

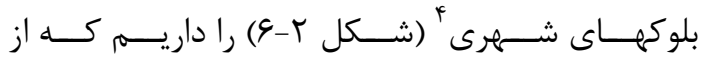

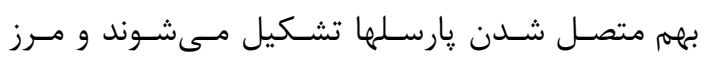

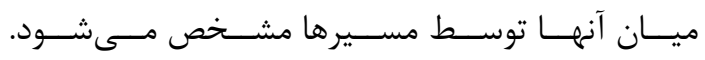

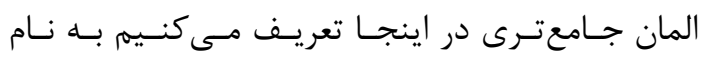

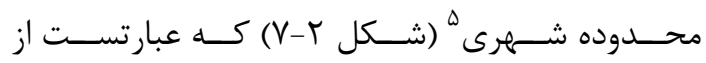

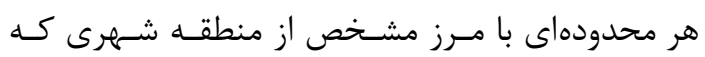

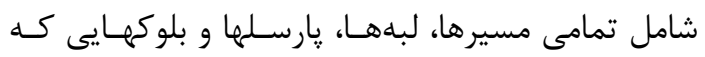

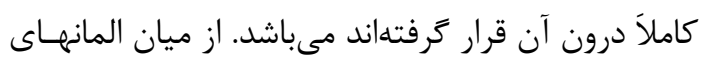

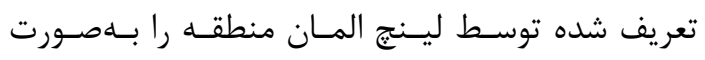

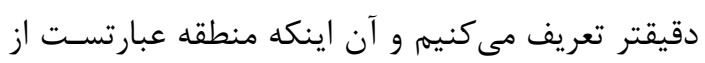

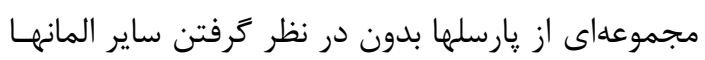

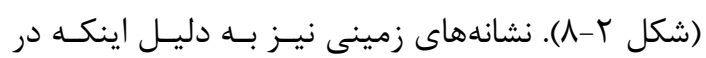

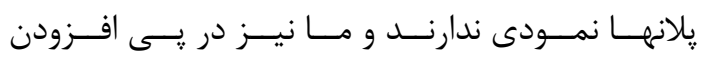

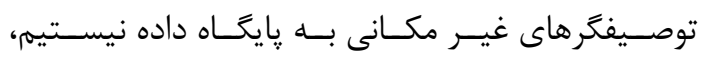

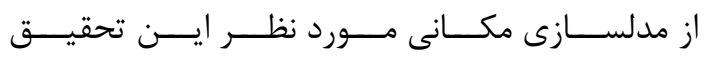

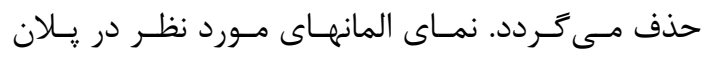
در شكل r نشان داده شدهاند.

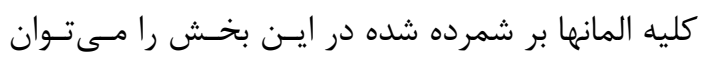

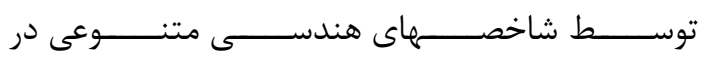

1 Parcels

2 Parcel boundary

3 Building lot

4 Blocks

5 Urban area 


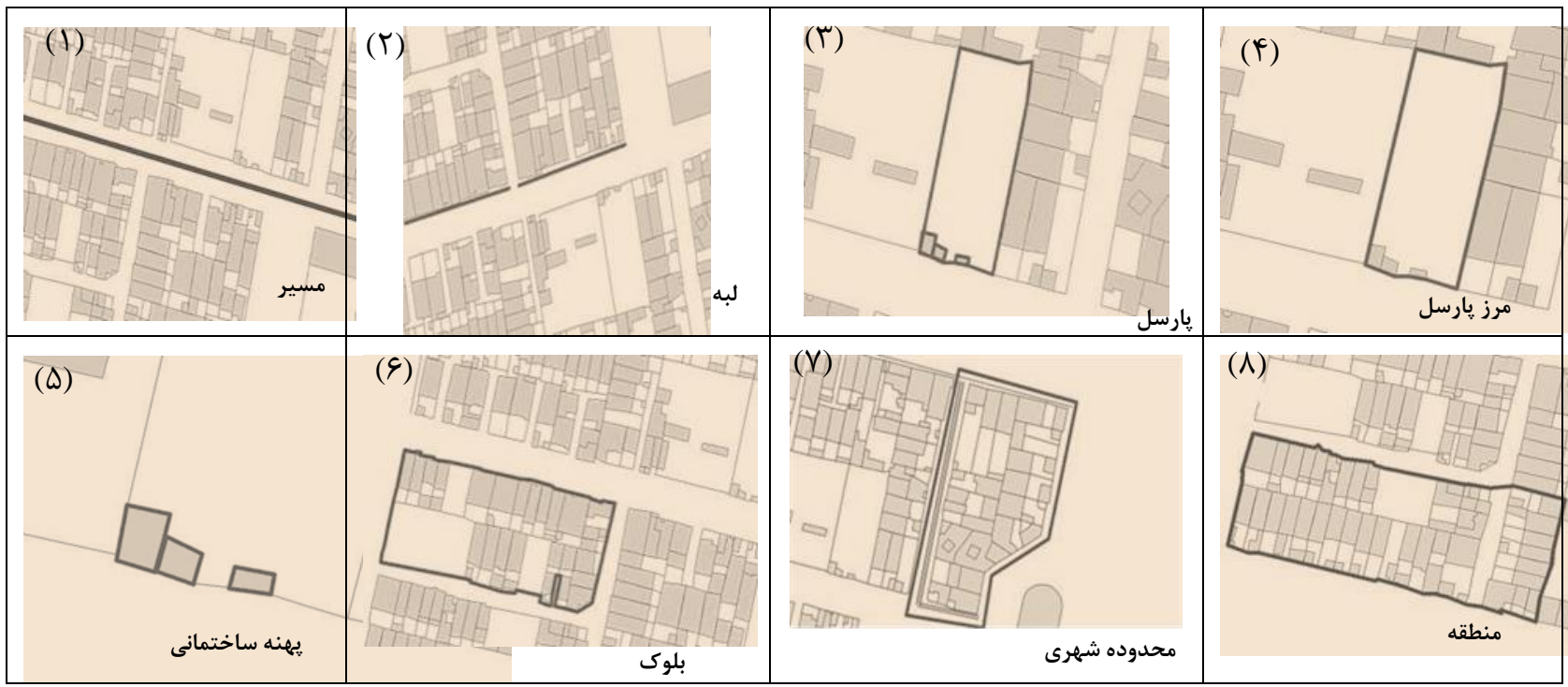

شكل r: المانهاى پِلان محيط شهرى كه موجوديتهاى پايخاه داده مكانى محيط شهرى شدهاند.

جدول ا: شاخصهاى اندازهيرى منظر كه براى اندازهَيرى المانهاى يلان شهرى بكار مىروند. در هر رديف المانى كه قادر به

اندازهزيرى توسط شاخص مىباشد با علامت * مشخص شده

\begin{tabular}{|c|c|c|c|c|c|}
\hline شاخص اندازهَيرى & توضيحات و روابط & نمايش & يارسل & بلوى بل & محدوده شهرى منطقه \\
\hline $\begin{array}{c}\text { مساحت } \\
\text { (AREA) }\end{array}$ & a & & $*$ & $*$ & $*$ \\
\hline $\begin{array}{c}\text { محيط } \\
\text { (PERIM) }\end{array}$ & $p$ & & $*$ & $*$ & $*$ \\
\hline نسبت محيط به & $\frac{\mathrm{p}}{\mathrm{a}}$ & & $*$ & $*$ & $*$ \\
\hline $\begin{array}{l}\text { شعاع زيراسيون' } \\
\text { (GYRATE) }\end{array}$ & $\sum_{i=1}^{n} \frac{h_{i}}{n}$ & & $*$ & $*$ & $*$ \\
\hline شاخص شكلr & $\frac{0.25 p}{\sqrt{a}}$ & & $*$ & $*$ & $*$ \\
\hline $\begin{array}{l}\text { شاخص بعد فركتالى } \\
\text { (FRAC) }\end{array}$ & $\frac{2 \ln (0.25 \mathrm{p})}{\ln \mathrm{a}}$ & & $*$ & $*$ & $*$ \\
\hline
\end{tabular}

1 Perimeter-Area Ratio

2 Radius of Gyration

3 Shape Index

4 Fractal Dimension Index 


\begin{tabular}{|c|c|c|c|c|c|}
\hline شاخص اندازهَيرى & توضيحات و روابط & نمايش & يارسل & بلوى بل & محدوده شهرى \\
\hline $\begin{array}{c}\text { 'مربع محيطى' } \\
\text { (SQUARE) }\end{array}$ & $\begin{array}{c}1-\frac{\mathrm{a}}{\mathrm{a}_{g}} \\
a_{s}\end{array}$ & & $*$ & $*$ & $*$ \\
\hline منطقه مركزى' & مشخصى از ناحيه مركزى يكى يهنه كه به فاصله & & $*$ & $*$ & $*$ \\
\hline $\begin{array}{c}\text { تعداد مناطق مركزى } \\
\text { (NCA) }\end{array}$ & تعداد CORE اى كه درون يك يهنه & & $*$ & $*$ & $*$ \\
\hline شاخص منطقه & $\frac{a_{c}}{a} * 100$ & & $*$ & * & $*$ \\
\hline $\begin{array}{l}\text { شاخص وضوح لبه } \\
\text { (ECON) }\end{array}$ & 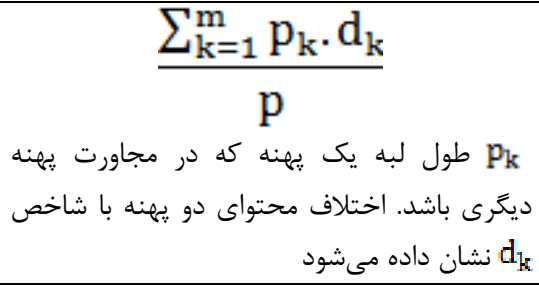 & & $*$ & & \\
\hline فاصله اقليدسى فيكترين همسايهُ & فاصله هر يهنه تا نزديكترين همسايهاش & & $*$ & $*$ & \\
\hline $\begin{array}{l}\text { شاخص نزديكىى } \\
\text { (PROX) }\end{array}$ & 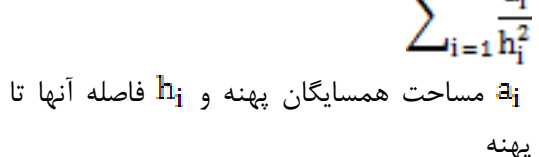 & & r & $*$ & \\
\hline درصد منظر^ & نسبتى از هر منظر كه توسط يك يهنه خاص & & & & $*$ \\
\hline $\begin{array}{c}\text { شاخص بزرگترين } \\
\text { يُهنه } \\
\text { (LPI) }\end{array}$ & 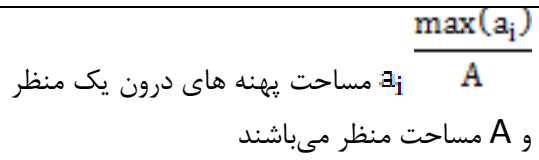 & & & $*$ & $*$ \\
\hline
\end{tabular}

1 Related Circumscribing Square

2 Core Area

3 Number of Core Area

4 Core Area Index

5 Edge Contrast Index

6 Euclidean Nearest Neighbor Distance

7 Proximity Index

8 Percentage of Landscape

9 Largest Patch Index 


\begin{tabular}{|c|c|c|c|c|c|}
\hline شاخص اندازهيرى & توضيحات و روابط & نمايش & يارسل & بلوى & محدوده شهرى منطقه \\
\hline $\begin{array}{l}\text { تعداد يهنه } \\
\text { (NP) }\end{array}$ & تعداد يِهنههاى درون يك منظر & & & $*$ & $*$ \\
\hline $\begin{array}{l}\text { "جكالى يهنه } \\
\text { (PD) }\end{array}$ & $\frac{\mathrm{NP}}{\mathrm{A}}$ & & & $*$ & * \\
\hline شاخص جدايى منظرَr & 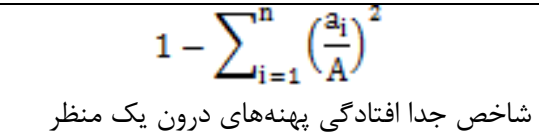 & & & $*$ & $*$ \\
\hline شاخص تفكيك & 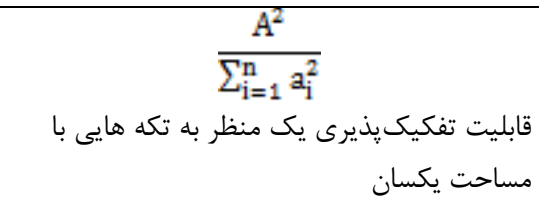 & & & $*$ & $*$ \\
\hline
\end{tabular}

جدول r: ساير شاخصهاى اندازهيرى هندسى بكار گرفته شده براى المانهاى كوناكون

\begin{tabular}{|c|c|c|c|c|}
\hline شاخص هندسى & توضيحات & لبه & مسير & 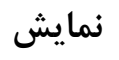 \\
\hline تقاطع ${ }^{d}$ (INT) & زاويه تقاطع بين دو مسير & & $*$ & \\
\hline $\begin{array}{c}{ }^{4} \text { طول) } \\
(\mathrm{LEN})\end{array}$ & طول يك تكه از مسير & & $*$ & \\
\hline $\begin{array}{l}\text { عرض } \\
\text { (WID) }\end{array}$ & عرض مسير & & $*$ & \\
\hline $\begin{array}{c}\wedge \\
\text { (BEND) } \\
\text { خمEN }\end{array}$ & براى بين دو سر آن بن بن عنول واقنى مسير و فاصله & & $*$ & \\
\hline
\end{tabular}

1 Number of Patches

2 Patch Density

3 Landscape Division Index

4 Splitting Index

5 Intersection

6 Length

7 Width

8 Bendiness 


\begin{tabular}{|c|c|c|c|c|}
\hline شاخص هندسى & توضيحات & لبه & مسير & بش \\
\hline هم ترازى' & 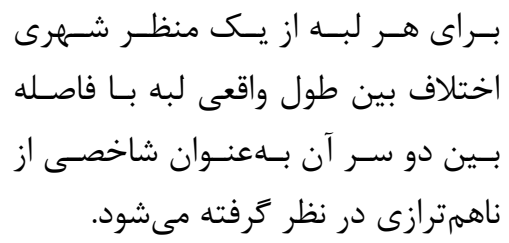 & $*$ & & \\
\hline 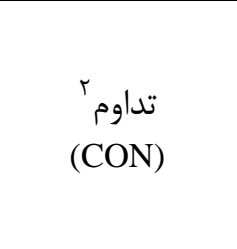 & 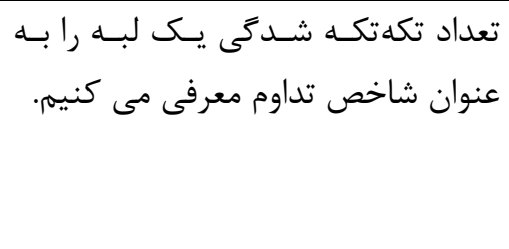 & $*$ & & \\
\hline تقارن & 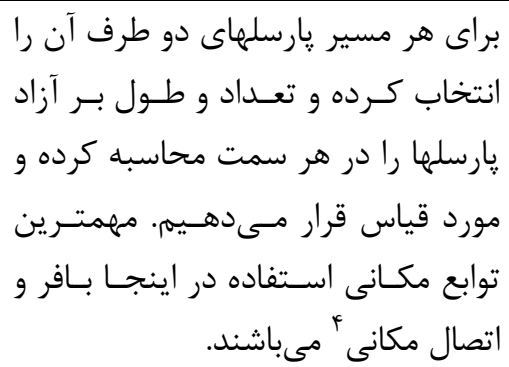 & & $*$ & \\
\hline
\end{tabular}

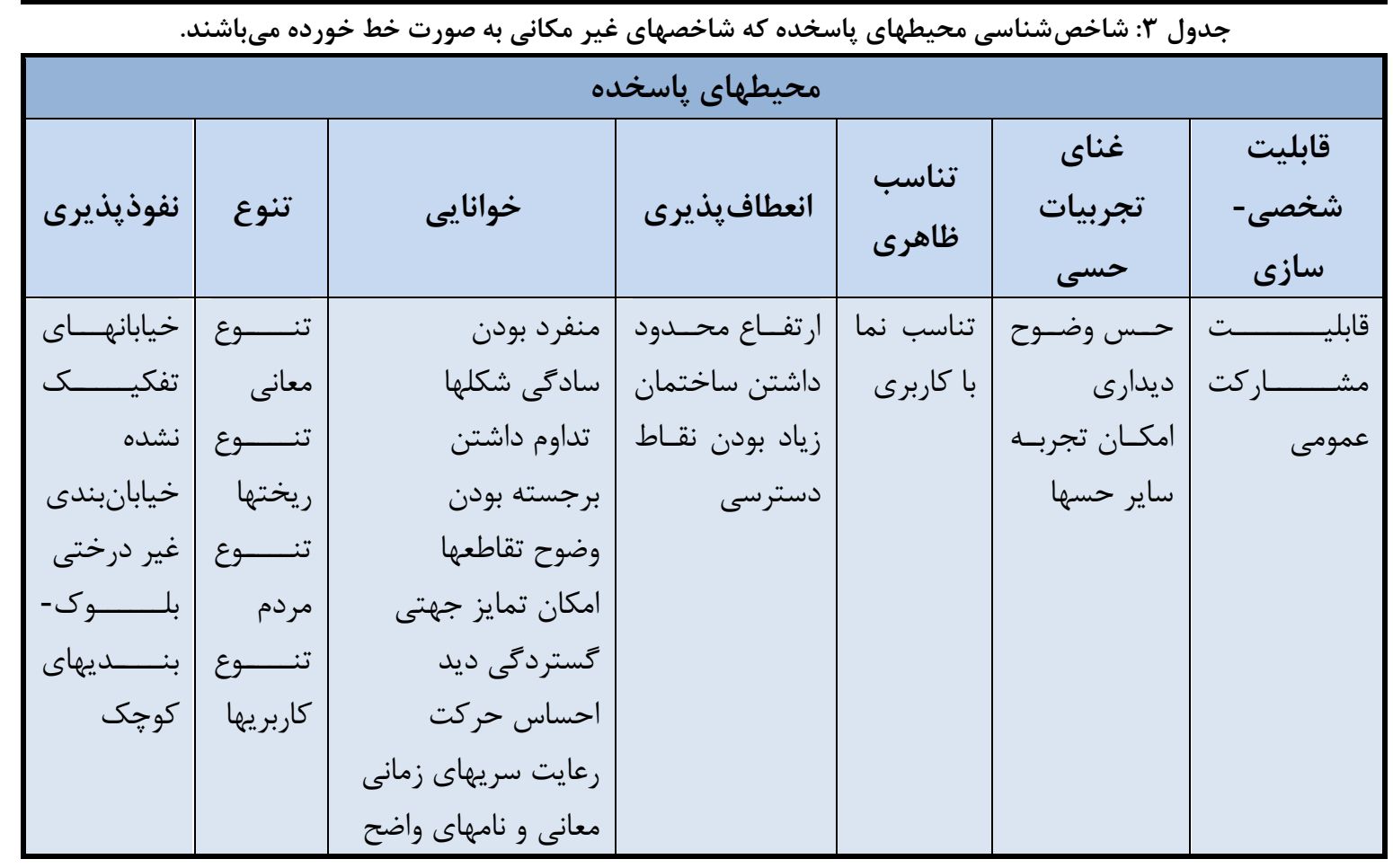

1 Alignment

2 Continuance

3 Symmetricalness

4 Spatial Join 
از ميان شاخصهاى ارائه شده در جدول بـ مـواردى كـهـ

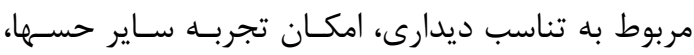

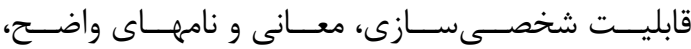

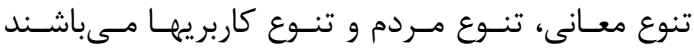

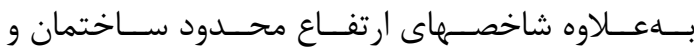

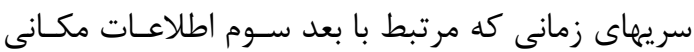

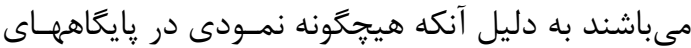
داده مكانى يلان شهرها ندارند از روند بررسـى كـاركرد

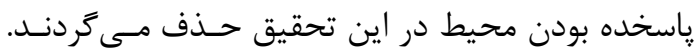

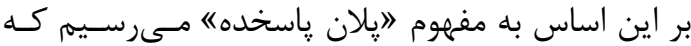

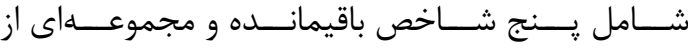
زيرشاخصهاى آنها مىباشد.

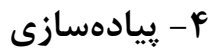

بdمنظور مطالعـه و بازيـابى كـاركرد ياسـخده بـودن در محيط پايگًاه داده مكانى لازم است كه مفهوم مورد نظر به نحوى وارد سيستم يايگاه داده شده و در مرحله بعـد

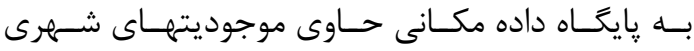
بهصورت مفهومى و فيزيكى تصوير شده و بر اين اساس

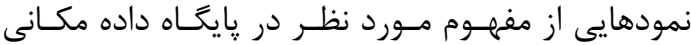

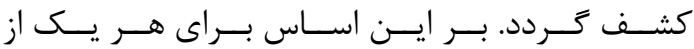

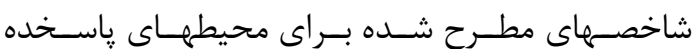
مىبايست تفسيرى هندسى در جهارجوب موجوديتهاى

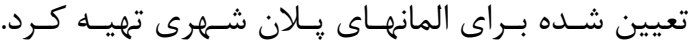
ايــن تفســير مبنــاى كشـف و بازيــابى شاخصـــــا در

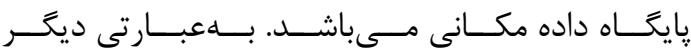
اجزاى محيطهاى ياسخده را با زبان اجـزاى رايخــاه داده

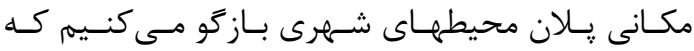

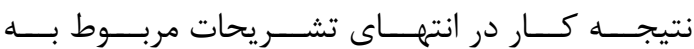
تفسير هندسى هـر شـاخص آمـده اسـت. نكتــهاى كـهـ

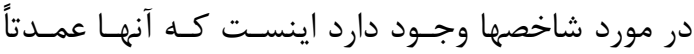
بيانكر مطلوبيت يا عدم مطلوبيت يك كميت مى مباشـند. در جنين مواقعى يك مقدار عددى بهعنوان حد آسـتانه

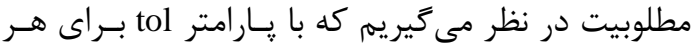
tol(Area) شاخص مشخص شده است. به عنـوان مثــال

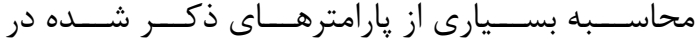

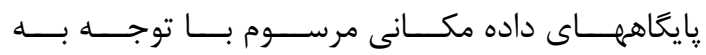
توابــع محاســباتى و آناليزهـــاى مكــانى كــهـ در آنهـــا وجود دارد به راحتى امكانيذير اسـت. در مـورد يـارامتر

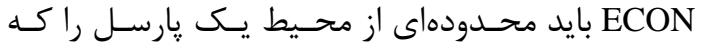

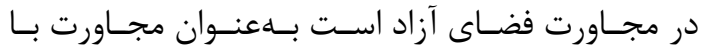
يههنه ديخر در نظر بخيريم و از تقسيم آن بر كل محسيط

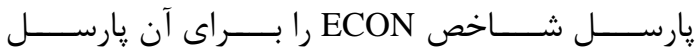

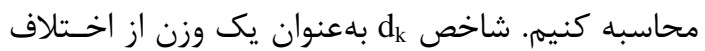
محتوايى هر يهنه با مجاورانش وارد محاسبات مسىشـود

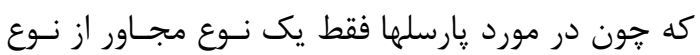

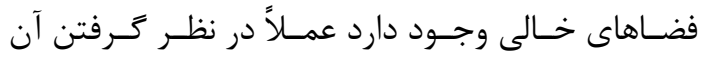

بىفايده مىباشد.

r-r - محيطهاى پاسخده

ايده اصلى اين مفهوم اينست كه محسـيط سـاخته شـده

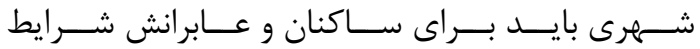

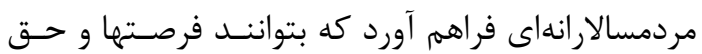

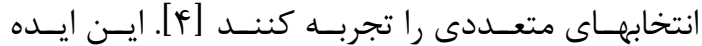
بر اساس هفت شاخص اصلى تشريح گرديده اسـت كـهـ اساس كار بازيابى كاركرد ياسخده بودن محيط در يلان

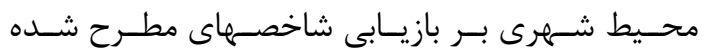

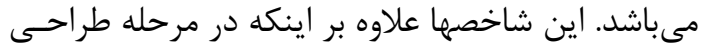
يك فضاى شهرى مىتوانــد مــورد توجـهـ قـرار كيرنـد جهت ارزيابى فضاهاى ساخته شدهاى كه در حال حاضر مورد استفاده هستند نيز كارايى دارند كه ايـن تحقيـق در راستاى مورد دوم بوده است. شاخصهاى معرفى شده

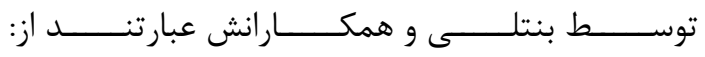
نفوذيـذيرى محــيط، تنــوع محـــيط، خوانـايـى محــيط،

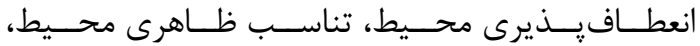

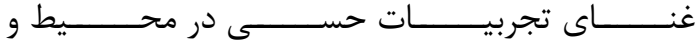

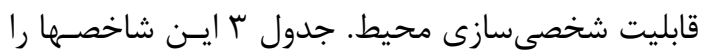
به همراه زيرشاخصمهاى هريك نشان مى نهد كـه بــراى

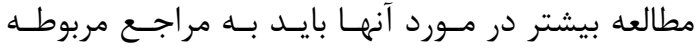

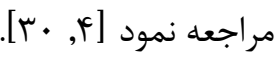


جدول ه: تفسير هندسى زيرشاخصهاى تنوع.

\begin{tabular}{|r|r|}
\hline تفسير هندسى & زير شاخص تنوع \\
\hline >tol(AREA_SD) \\
\hline
\end{tabular}

r. خوانايى: عابرين بايد توانايى فهرم ساختار فضـايى

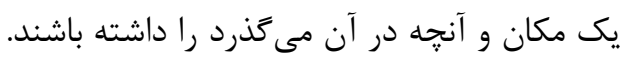

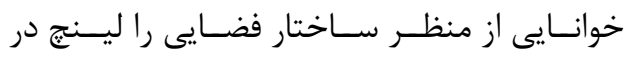

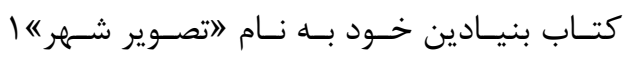
[r.]

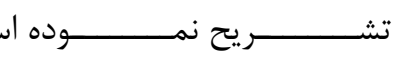

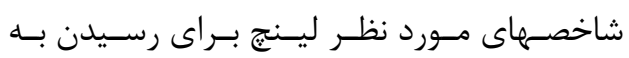

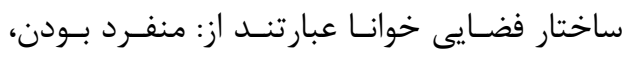

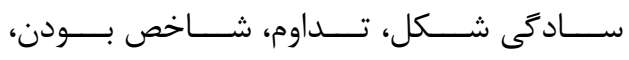

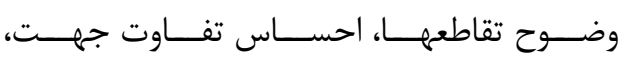

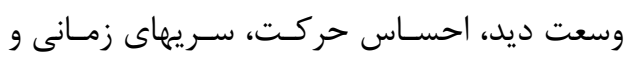

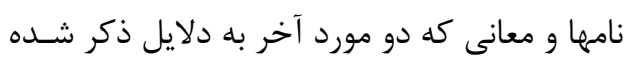

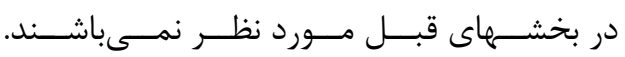

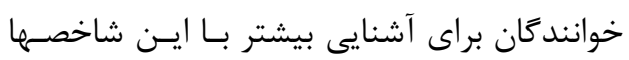

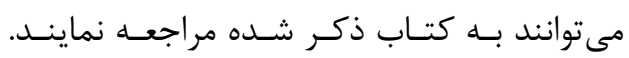
منفرد بودن به معناى توانايى تشخيص فـرد فـرد

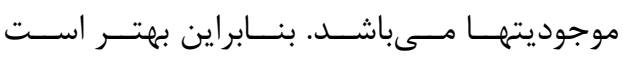

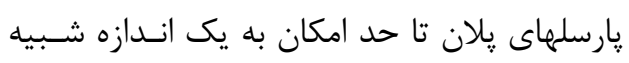

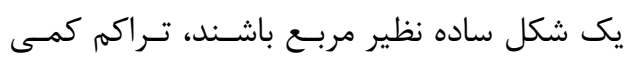

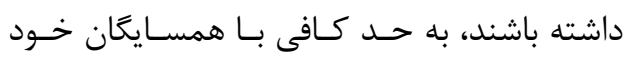

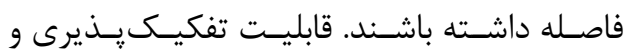
جدافتادكى بالا نيز به اين شاخص كمك مى كند.

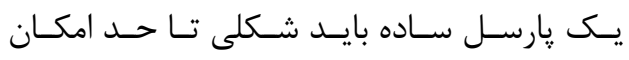

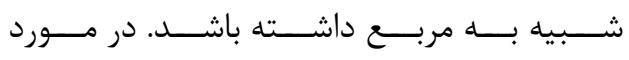

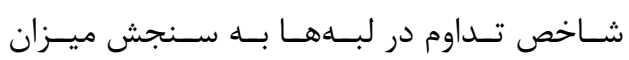

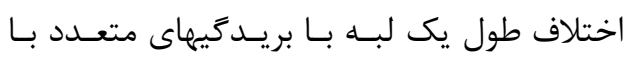

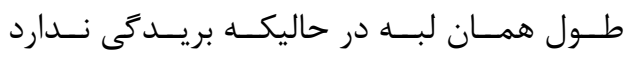

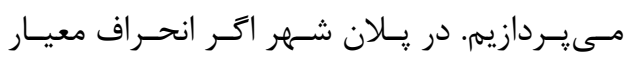

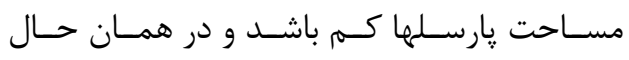

بـــه معنــاى حـــد آســتانه كميــت مســاحت بـــراى كوجى شمرده شدن يا بزرگ شمرده شدن يك يهنه يا

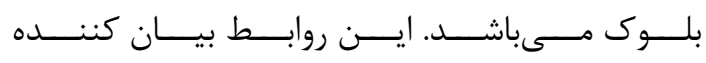
تفسيرهاى هندسى در جداول ع أنا م آمدهاند.

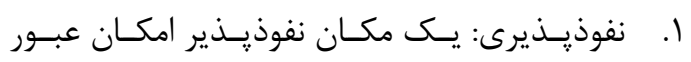

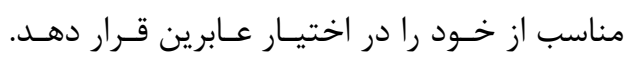

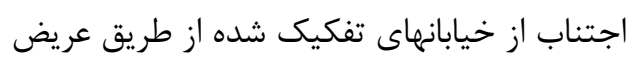

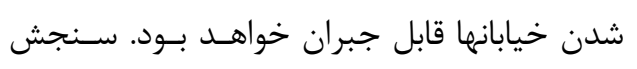

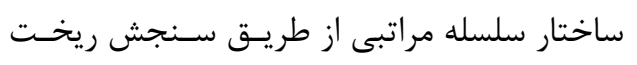

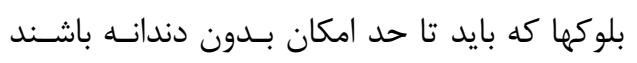

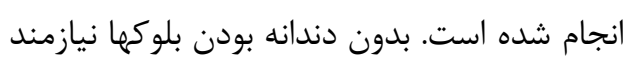

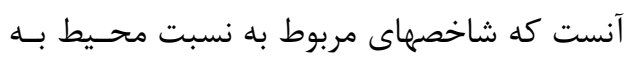
مساحت بلوك تا حد امكان كو جكى باشند. جدول f: تفسير هندسى زير شاخصهاى نفوذيذيرى.

\begin{tabular}{|c|c|}
\hline زير شاخصهاى نفيذيرى & تفسير هندسى \\
\hline بلوكبندى با ابعاد & 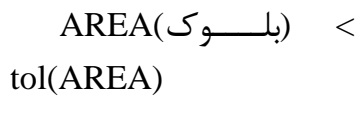 \\
\hline اجتناب از خيابانهاى & $\begin{array}{l}\text { WID(مســــ } \\
\text { tol(WIDTH) }\end{array}$ \\
\hline بنديهاى سلسله از خيابان - & 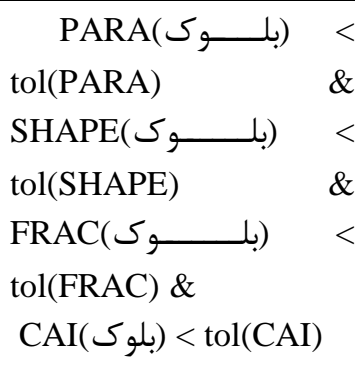 \\
\hline
\end{tabular}

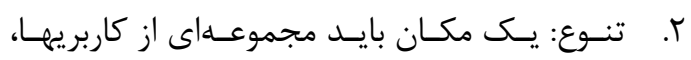

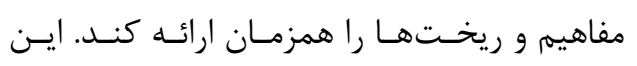

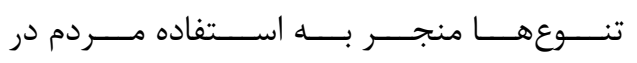

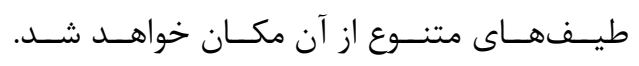

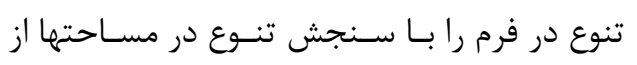
طريق گارامتر انحراف معيار سنجيدهايم.

1 The Image of the City 


\begin{tabular}{|c|c|}
\hline سكلى سادى & 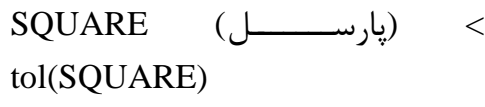 \\
\hline تداوم & 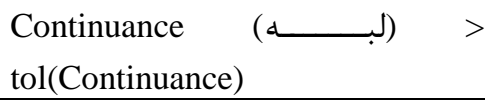 \\
\hline شاخص & $\begin{array}{l}\text { AREA_SD(منطقd) } \\
\text { tol(AREA_SD) } \\
\text { AREA_RA(منطقــ } \\
\text { tol(AREA_RA) }\end{array}$ \\
\hline وضوح & 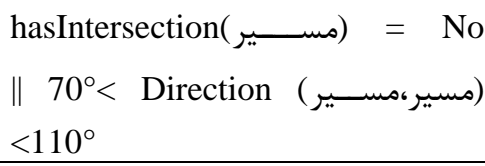 \\
\hline جفاوت & 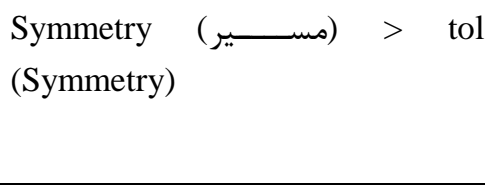 \\
\hline وسعت & 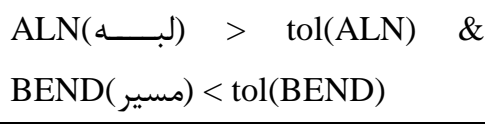 \\
\hline احساس & BEND (مسير) tol(BEND) \\
\hline
\end{tabular}

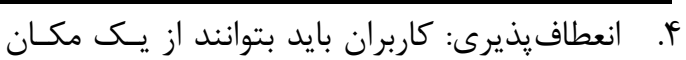

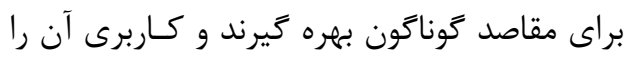

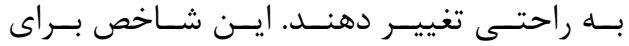

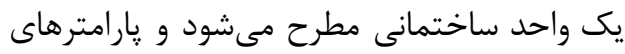

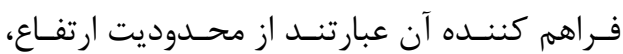
وجود نقاط ورود و دسترسى به حد كـافى و زيـاد نبــودن عمــق ســاختمان در يــلان. در مـــورد

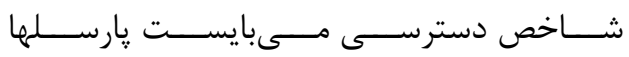

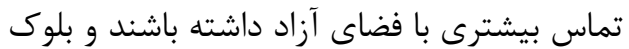

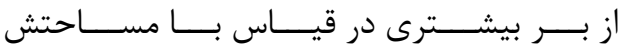
برخوردار باشد.

جدول V: تفسير هندسى زيرشاخصهاى انعطاف يذيرى.

\begin{tabular}{|c|c|}
\hline زير شاخصهاف يذيرى & تفسير هندسى \\
\hline دسترسى به حد & $\begin{array}{c}\text { PARA(بلوك) > } \\
\text { tol(PARA) \& } \\
\text { ECON(يارسل) > } \\
\text { tol(ECON) }\end{array}$ \\
\hline
\end{tabular}

بازه تغييرات آنها زياد باشد بهمعنــاى آنسـت كـهـ

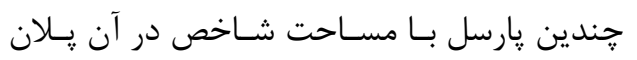
وجود دارد. درمورد خيابانها در صورتيكه تقـاطعى لنى

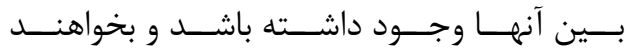

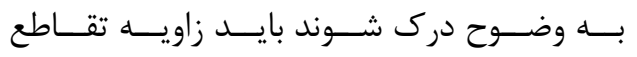

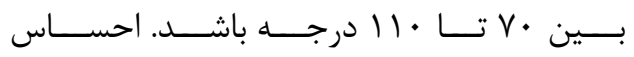

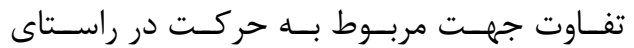

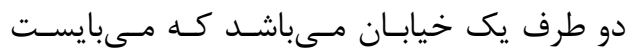

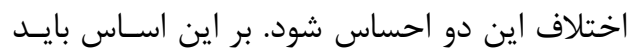
يارسلهاى مقابل هم در دوطرف خيابـان اخـتلاف

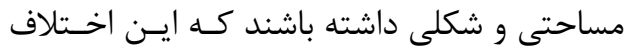

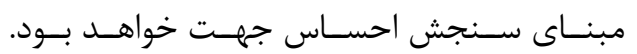

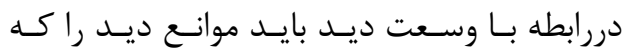

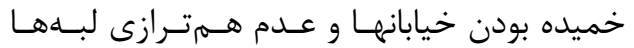
مىباشد مورد سنجش قرار دهيم. احساس حركت

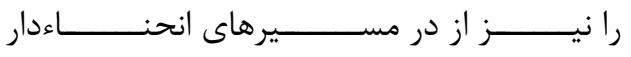
مورد سنجش قرار مى دهيم.

جدول 9: تفسير هندسى زيرشاخصهاى خوانايى.

\begin{tabular}{|c|c|}
\hline شاخص زير & تفسير هندسى \\
\hline منفرد & 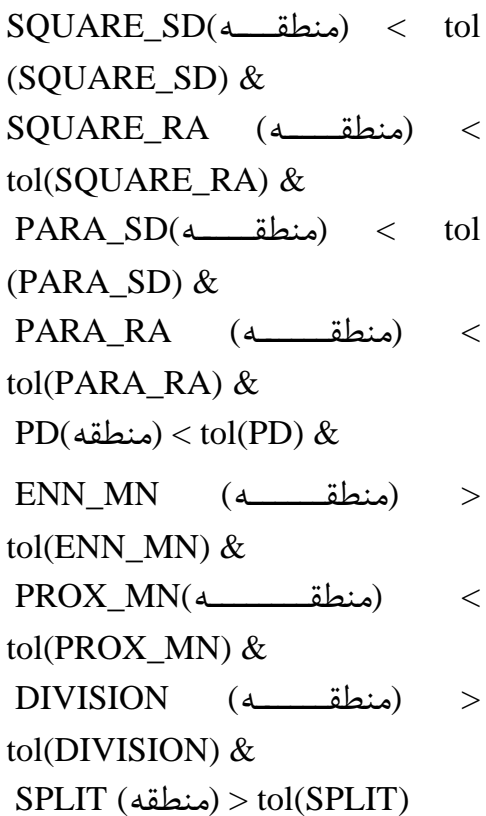 \\
\hline
\end{tabular}




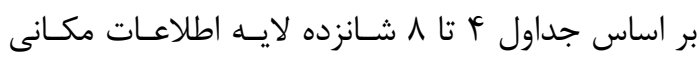

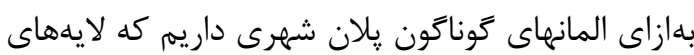

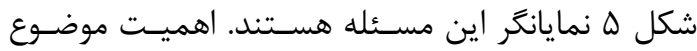

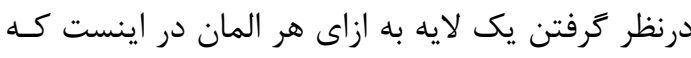

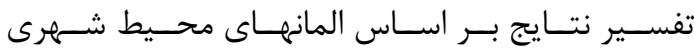

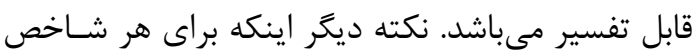
ميانكين آن در كل محدوده مطالعاتى به عنوان آسـتانه

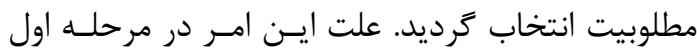

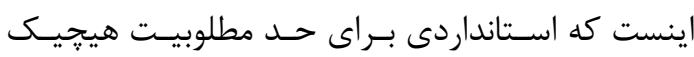
وجود ندارد و در مرحله بعد اين روند منجر به كشـف و ودائ

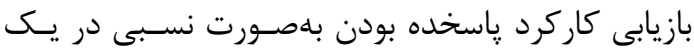

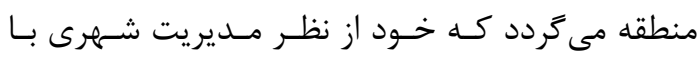

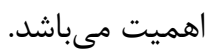

$$
\text { ه- ارزيابى نتايج }
$$

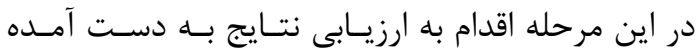

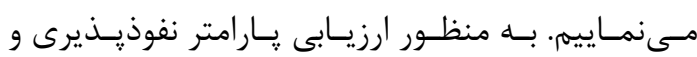

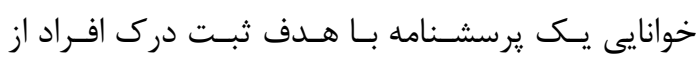

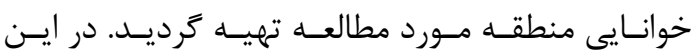

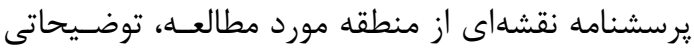

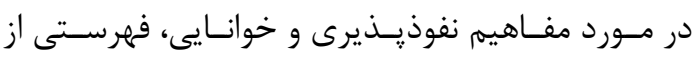

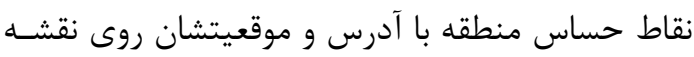

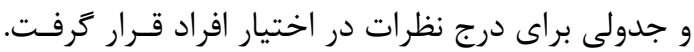

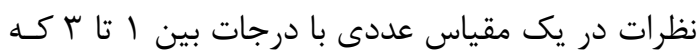

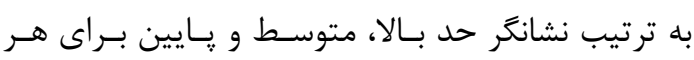

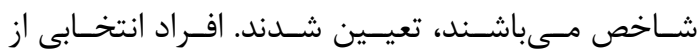

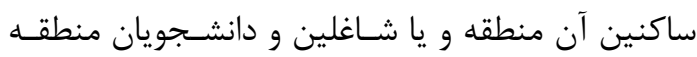

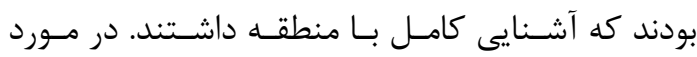

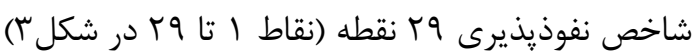
در سطح منطقه تعريف كرديم و براى شاخص خوانـايى

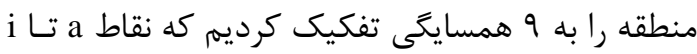

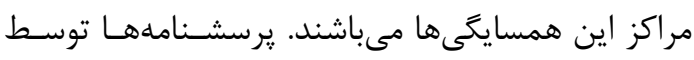

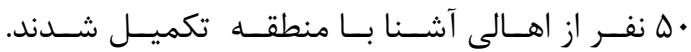

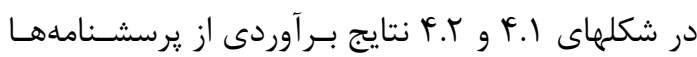

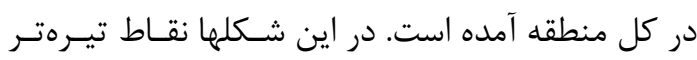

ه. غنـاى حسـها: امكـان تجربـه حسـهاى كَونـاكون

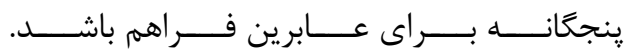

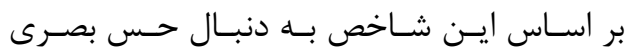

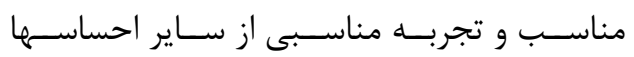

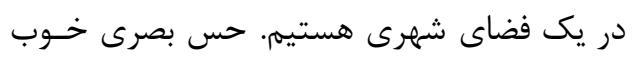

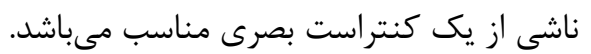

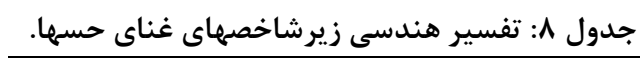

\begin{tabular}{|c|c|}
\hline زير شاخصهاى حسهاى & تفسير هندسى \\
\hline خوبس بصـــرى & $\begin{array}{l}\text { AREA_SD(منطق_ـــــ) } \\
\text { tol(AREA_SD) }\end{array}$ \\
\hline
\end{tabular}

در اين مرحله به دنبال آن هستيم كه به نحوى مفهـوم

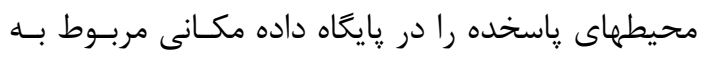

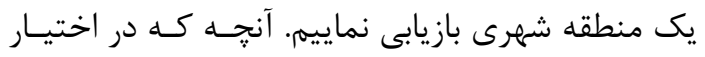

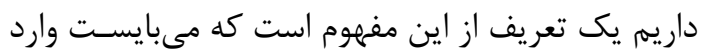

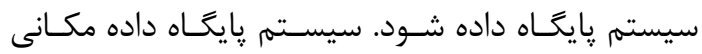

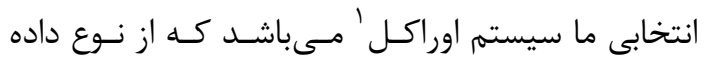

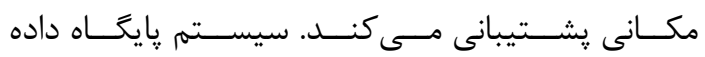

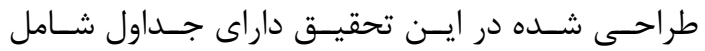

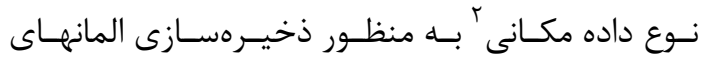

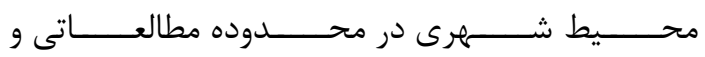
شاخصهاى هندسى آنها مىباشد.

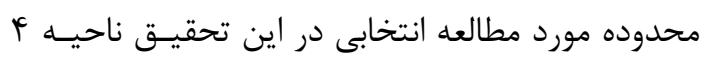

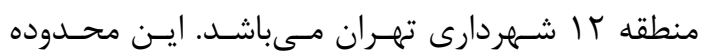

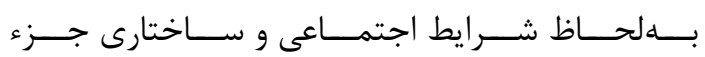

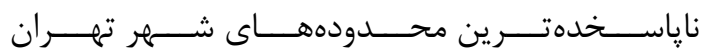

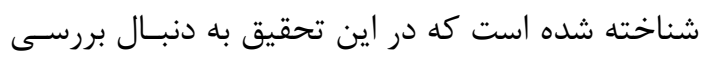

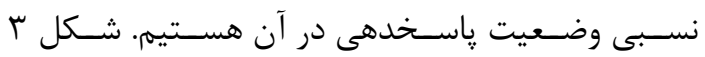

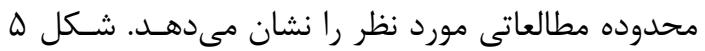

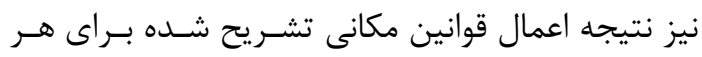

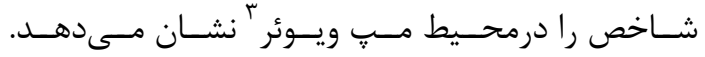

1 Oracle

2 SDO_GEOMETRY

3 Map Viewer 


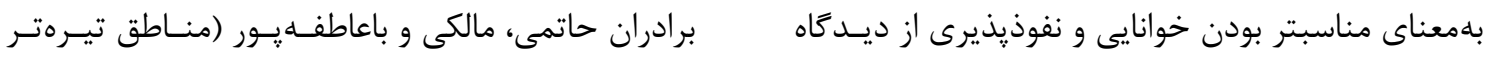

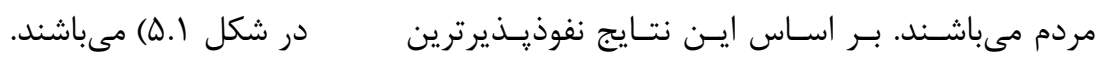
محسدودههـا در ايسن منطقــه در خيابانهـاى نصـيرى،

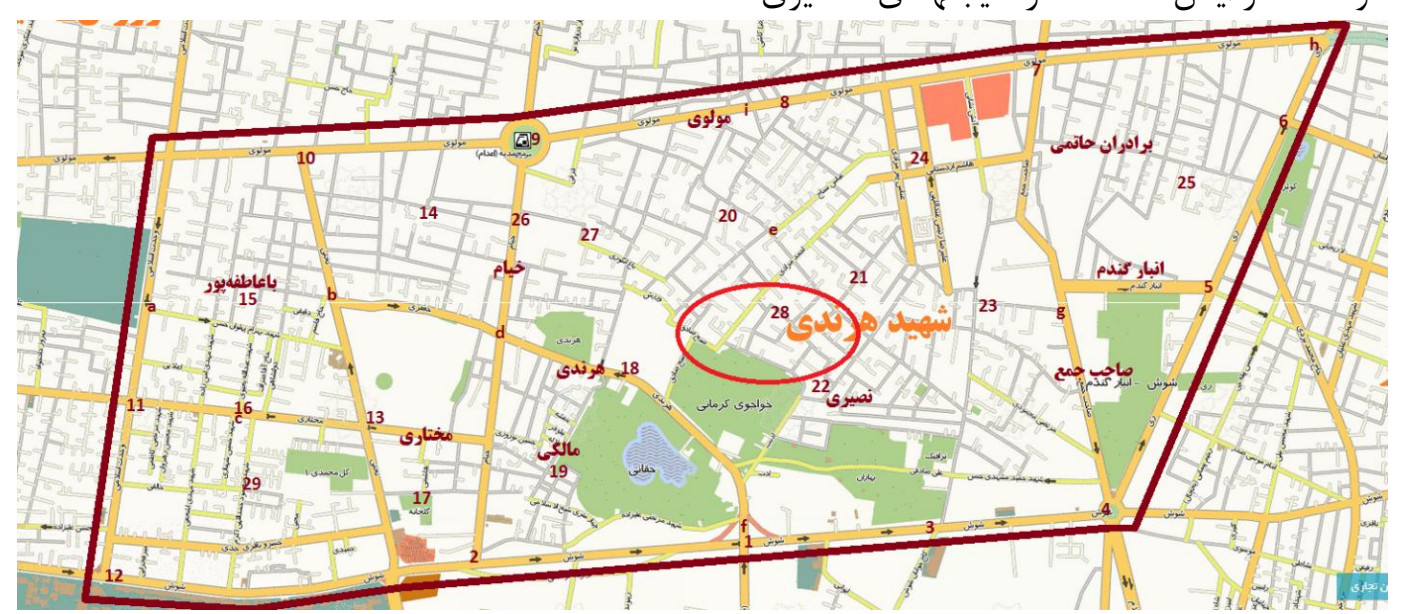

شكل r: ناحيه f منطقه rا شهردارى تهران به عنوان محدوده مطالعاتى. خيابانهاى مههم و نقاط برداشت نظرات مردم درباره نفوذيذيرى و خوانايى

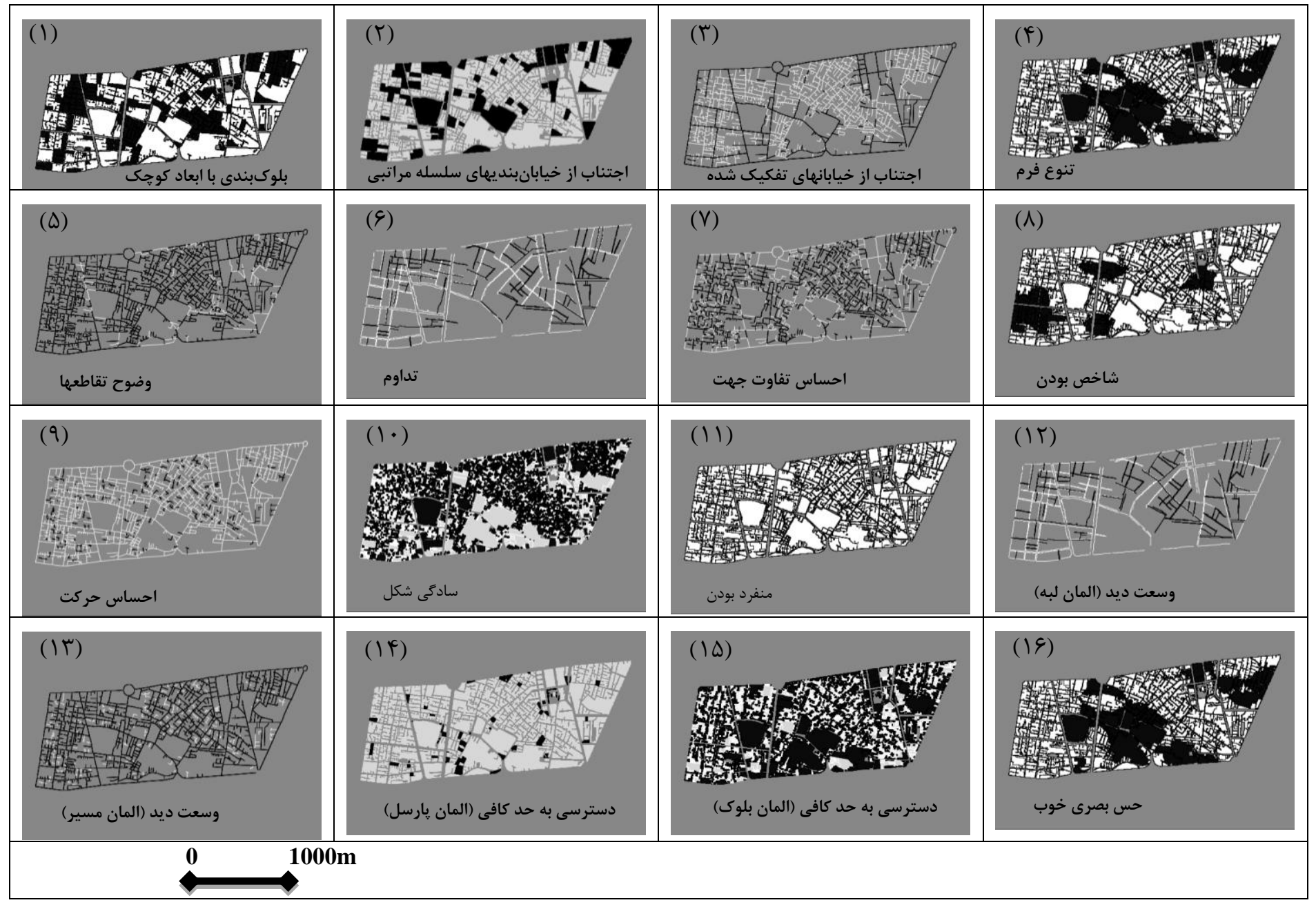

شكل F: لايههاى خروجى براى هر يك از تفسيرات هندسى محيطهاى ياسخده در يايگاه داده مكانى 


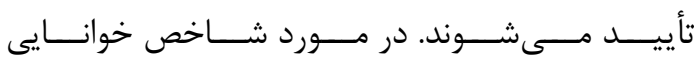

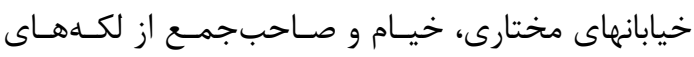

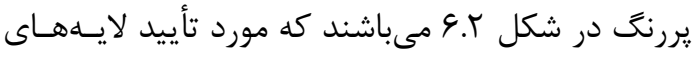

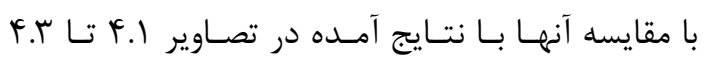

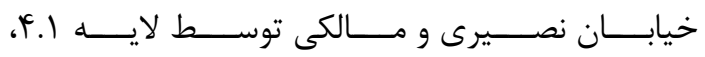

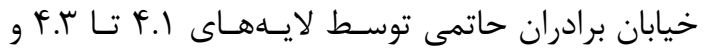

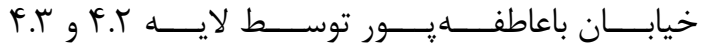

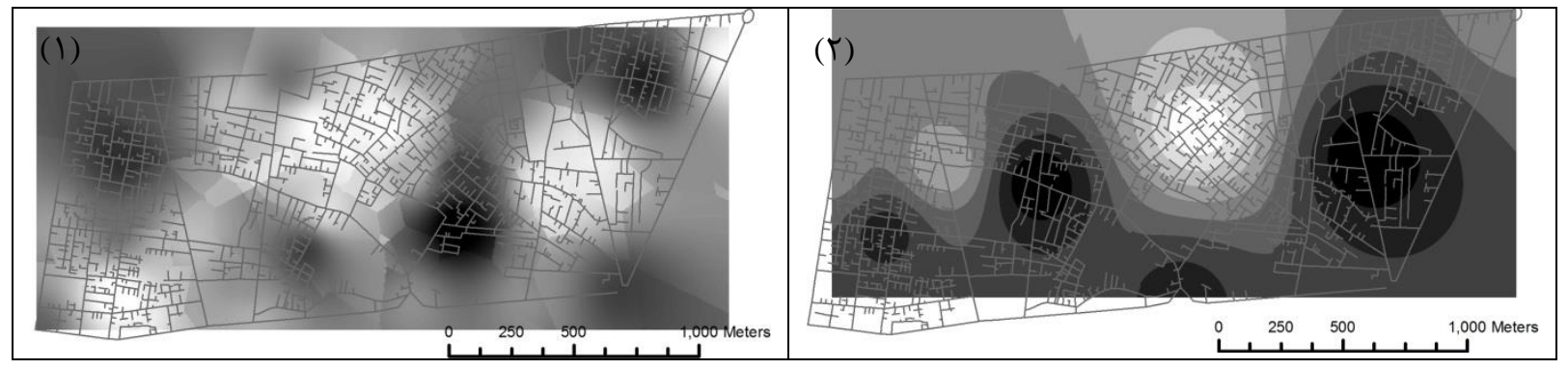

شكل ه: لايههاى رسترى شده نظرات مردم درباره (1) نفوذيذيرى و (r) خوانايى.

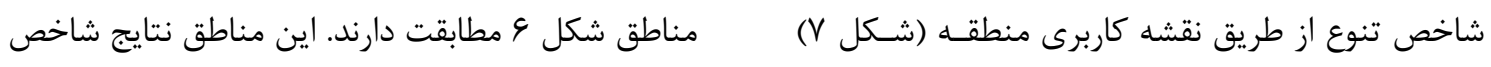

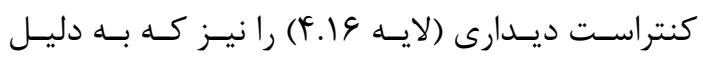

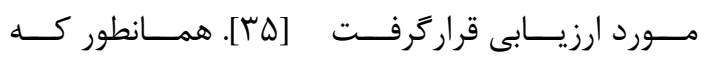
اختلاف زياد مساحت يارسلها مىباشد، تأييد مى كنند.

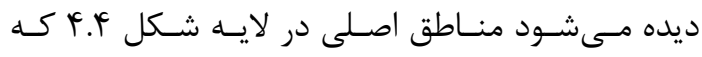
متنوعترين مناطق تشخيص داده شدهاند با متنوعترين درين

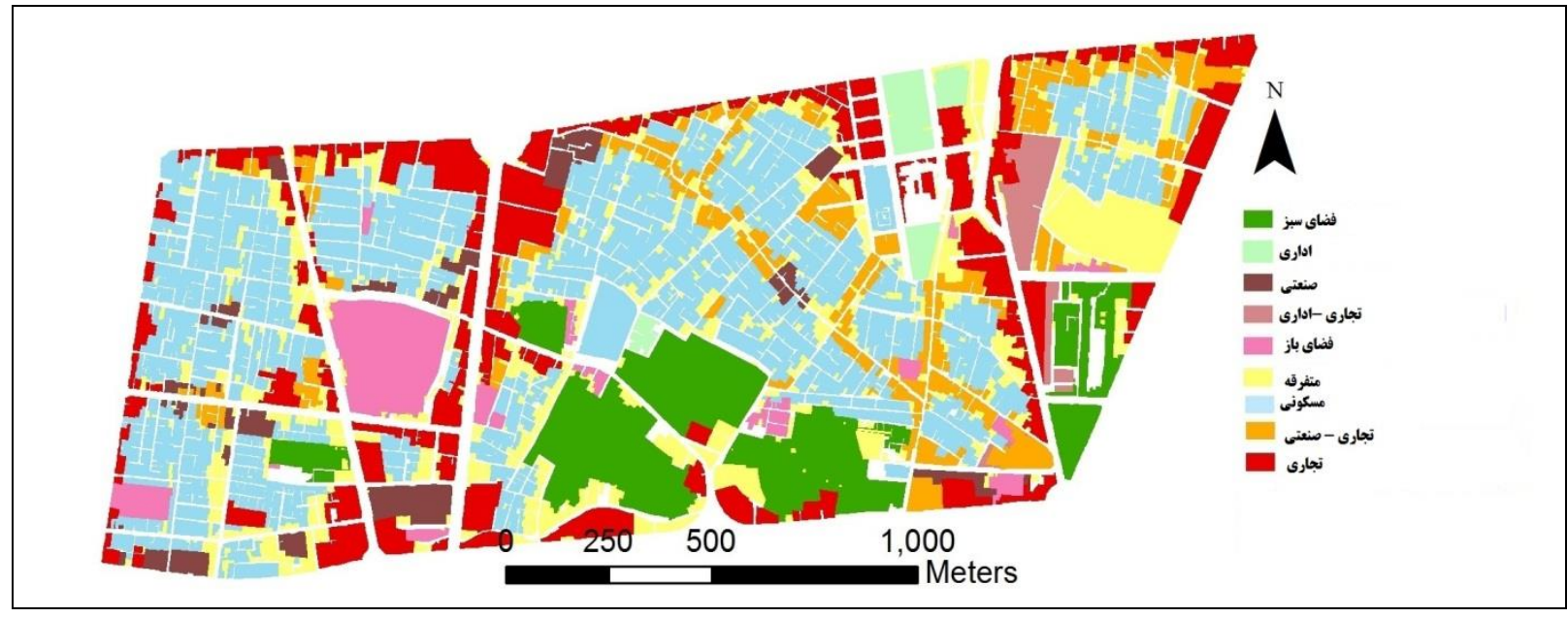

شكل 9: نقشه كاربرى محدوده مطالعاتى

خيابانهاى صاحبجمع، انباركندم و خيام اتفاق افتادهاند

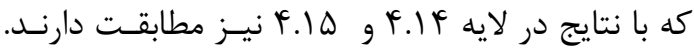

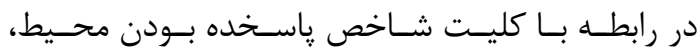

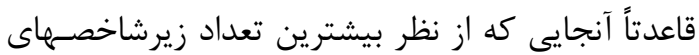

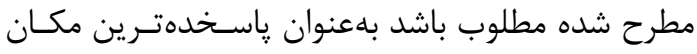

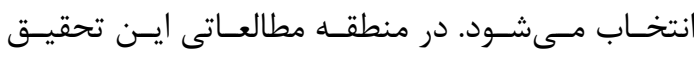

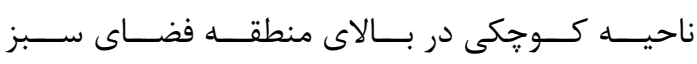

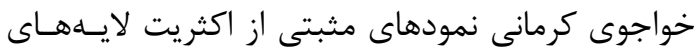

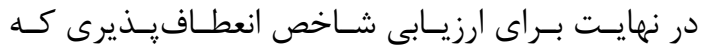

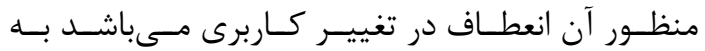

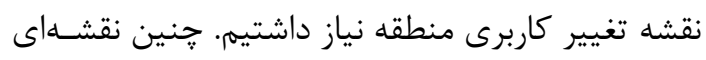

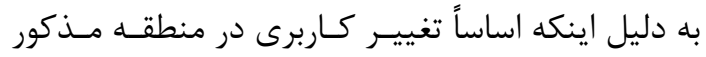

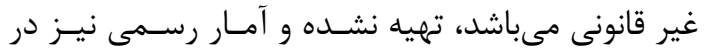

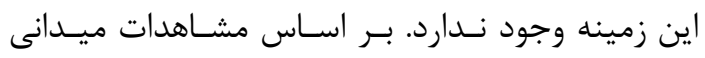

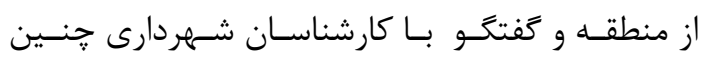
بر مسى آيــــــهـ بيشـترين تغييـر كاربريهـا در محـدوده 
در نهايت با استفاده از قابليت تعريف قانون در سيسـتم يايگًاه داده تفسير هندسى يارامترهاى مفهوم مورد نظـــ به سيستم وارد شده و يايه كشف آن مفهوم با اسـتفاده

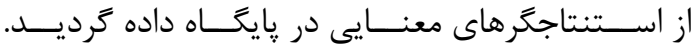
مفهوم مورد نظر در اين تحقيق "محيطهـاى ياسـخده"

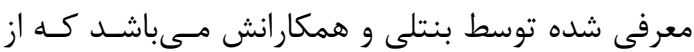

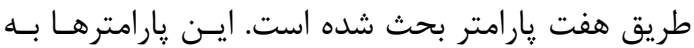

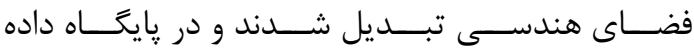

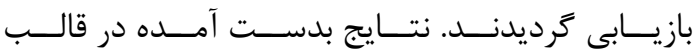

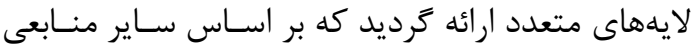
كه به نظر مرتبط مى آمــ، مـورد ارزيـابى واقـع شـدند.

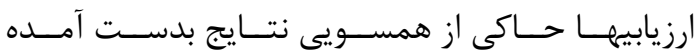

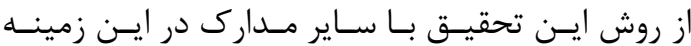

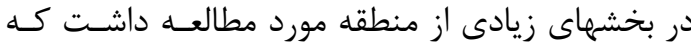

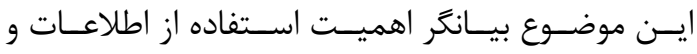

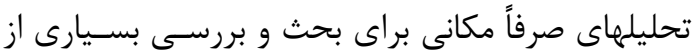

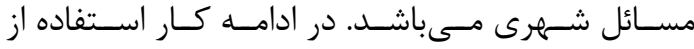

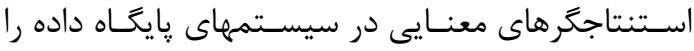

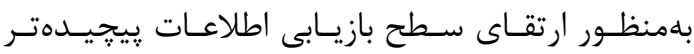
معنايى از روابط مكانى ييشنهاد مى كنيم.

[1] H. Blumenfeld, "Form and Function in Urban Communities," Journal of the American Society of Architectural Historians vol. 3, pp. 11-21, 1943.

[2] H. Greenough. (1947). Form and Function: Remarks on Art.

[3] S. M. Shalabi, "Analysis of Urban Morphology for Real Time Visualization of Urban Scenes," Master of Engineering in Electrical Engineering and Computer Science, Department of Electrical Engineering and Computer Science, MASSACHUSETTS INSTITUTE OF TECHNOLOGY, 1998.

[4] I. Bentley, A. Alcock, P. Murrain, S. McGlynn, and G. Smith, Responsive environments: A Manual for designers.
مورد بحث دارد. اين منطقه با يك بيضى قرمز در شكل

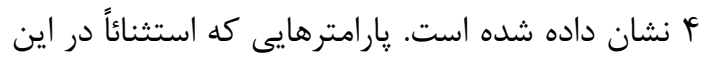
منطقه صادق نيستند موارد شاخص بودن(شـكل ^.؟F) و وسعت ديد مرتبط با لبهها (شكل r.|F) مىباشند.

\section{9- جمعبندى و ييشننهادات}

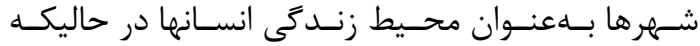
تحت تأثير تصميمات انسانى براى طراحى، ساختاردهى و توسعه مىباشند، مى توانند به عنوان يكى محـيط يويــا

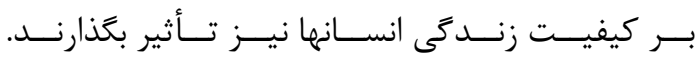
بر همين اساس مطالعه جنبههاى گونـاكون يـك شـهر مى تواند راهى براى شناخت و تفسير بسيارى از مسـائل

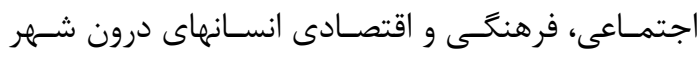
باشد. در اين مقاله شناخت شهر را از منظـر فيزيكى و

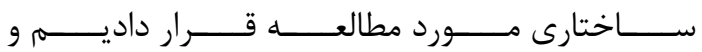
يايخاهرهاى داده مكانى و قابليتهاى آنها را بـدين منظــور بررسى نموديم. روشى براى شناخت مسئله مــورد نظــر معرفى نموديم كه قابليت تفسير در سيستم يايخـاه داده مكانى را داشته باشد. يكى پايعاه داده مكانى مــرتبط بـا اجـزاى فيزيكـى شـهر طراحسى گرديــد و فهرسـتى از

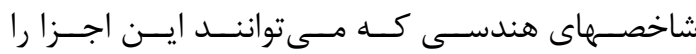

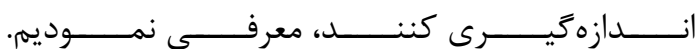

London: The Architectural Press, 1985.

[5] H. Bahrainy, H. Khosravi, "Effective Physiacal and Spatial parameters on pedestrian's health and Body Fitting," Journal of Fine Arts, Architecture and Urbaning, vol. 43, pp. 16-5, 1389 (Persian).

[6] M. Abbaszadegan, S. Mokhtarzadeh, R. Bidram, "A study of the relation between the spatial structure of the city and the quality of urban development using Space Syntax A case study of Mashhad," Urban - Regional Studies and Research Journal, vol. 4, pp. 6243, 1391 (Persian).

[7] D. Stead and S. Marshall, "The Relationships between Urban Form and Travel Patterns. An International Review and Evaluation," European Journal of 
Transport and Infrastructure Research, vol. 1, pp. 113 - 141, 2001.

[8] M. R. Pourjafar and A. A. Taghvaee, "Urban Design Criteria for Earthquake Preparedness in Organic Urban Areas of Tehran," Humanities vol. 12, pp. 13-20, 2005.

[9] D. Contreras, T. Blaschke, S. Kienberger, and P. Zeil, "Spatial connectivity as a recovery process indicator: The L'Aquila earthquake," Technological Forecasting and Social Change, vol. 80, pp. 1782-1803, 2013.

[10] G. Rybarczyk and C. Wu, "Examining the impact of urban morphology on bicycle mode choice," Environment and Planning B: Planning and Design, vol. 41, pp. 272-288, 2014.

[11]B. Jiang and C. Claramunt, "A structural approach to the model generalisation of an urban street network,", Geoinformatica, vol. 8, pp. 151-171, 2004.

[12]B. Jiang and C. Claramunt, "Topological analysis of urban street networks," Environmental Planning B, vol. 31, pp. 151162, 2004.

[13]L. Khirfan, "Exploring isovist fields: space and shape in architectural and urban morphology," Cities vol. 27, pp. 315-325, 2010.

[14] Y. Chena, X. Li, Y. Zheng, Y. Guan, and X. Liu, "Estimating the relationship between urban forms and energy consumption: A case study in the Pearl River Delta, 20052008," Landscape and Urban Planning vol. 102, pp. 33-42, 2011.

[15] Y. Duan and F. Lu, "Structural robustness of city road networks based on community," Computers, Environment and Urban Systems, vol. 41, pp. 75-87, 2013.

[16] M. Tomko and S. Winter, "Describing the functional spatial structure of urban environments," Computers, Environment and Urban Systems, vol. 41, pp. 177-187, 2013.

[17]B. Hillier and J. Hanson, The Social Logic of Space. Cambridge: Cambridge University Press, 1984.

[18]B. Jiang, C. Claramunt, and B. Klarqvist, "Integration of space syntax into GIS for modelling urban spaces " International Journal of Applied Earth Observation and Geoinformation, vol. 2, pp. 161-171, 2000.

[19]B. Jiang and C. Liu, "Street-based topological representations and analyses for predicting traffic flow in GIS," International Journal of Geographical Information vol. 23, pp. 1119-1137, 2009.

[20]O. Rismanchian, S. Bell, and S. Mokhtarzadeh, "Identifying Accessibility Problems In Deteriorated Urban Areas, A Case Study Of Tehran, Iran," in Eighth International Space Syntax Symposium, Santiago de Chile, 2012.

[21] M. Eeftens, J. Beekhuizen, R. Beelen, M. Wang, R. Vermeulen, B. Brunekreef, et al., "Quantifying urban street configuration for improvements in air pollution models," Atmospheric Environment, vol. 72, pp. 1-9, 2013.

[22] J. A. Futcher, T. Kershawb, and G. Mills, "Urban form and function as building performance parameters," Building and Environment vol. 62, pp. 112-123,2013.

[23] T. Liu, Y. Luan, and W. Zhong, "Earthquake responses of clusters of building structures caused by anear-field thrust fault," Soil DynamicsandEarthquakeEngineering, vol. 42, pp. 56-70, 2012.

[24] X. Gainza and F. Livert, "Urban form and the environmental impact of commuting in a segregated city, Santiago de Chile," Environment and Planning B: Planning and Design, vol. 40, pp. 507-522, 2013.

[25] M. Herold, H. Couclelis, and K. C. Clarke, "The role of spatial metrics in the analysis and modeling of urban land use change," Computers, Environment and Urban Systems, vol. 29, pp. 369-399, 2005.

[26] C. Fan and S. Myint, "A comparison of spatial autocorrelation indices and landscape metrics in measuring urban landscape fragmentation," Landscape and Urban Planning, vol. 121, pp. 117-128, 2014.

[27] I. G. D. Filicaia, "The housing forms and urban morphology of poverty areas in the London borough of Islington," Master of Science, University College London, 2007.

[28] P. Edussuriya, A. Chan, and A. Yec, "Urban morphology and air quality in dense residential environments in Hong Kong. Part I: District-level analysis," Atmospheric Environment vol. 45, pp. 4789-4803, 2011.

[29] M. C. D. Lay, A. Reis, V. Dreux, and D. Becker, "Urban Security and Spatial Behavior: syntactic and perceptual analysis of the central area of Porto Alegre," presented at the 6th International Space Syntax Symposium, İstanbul, 2007. 
[30]K. Lynch, The Image of the City. Cambridge, Massachusetts: The MIT Press, 1960.

[31]K. McGarigal, and B. Marks "FRAGSTATS: spatial pattern analysis program for quantifying landscape structure," U.S. Forest Service General Technical Report PNW-GTR-351, 1995.

[32]F. Aguilera, L. M. Valenzuelaa, and A. Botequilha-Leitãob, "Landscape metrics in the analysis of urban land use patterns: A case study in a Spanish metropolitan area," Landscape and Urban Planning, vol. 99, pp. 226-238, 2011.

[33]E. J. Gustafson, " Quantifying landscape spatial pattern: What is the state of the art," Ecosystems, vol. 1, pp. 143-156, 1998.

[34]T. V. d. Voordea, W. Jacquet, and F. Cantersa, "Mapping form and function in urban areas: An approach based on urban metrics and continuous impervious surface data," Landscape and Urban Planning, vol. 102 pp. 143-155, 2011.

[35] TehranMunicipality, "Developing Plan for District 12," U.d.a. architecture, editor. Tehran Municipality, Tehran 88, 2006 (Persian). 


\title{
Studying and Retrieving the Urban Functionalities based on Morphological Analysis (The Studied Function: Responsive Environments)
}

\author{
Tolo Silavi. $*^{1}$, Farshad Hakimpour ${ }^{2}$, Farshad Nourian ${ }^{3}$ \\ 1-PhD. student of GIS in Department of Geomatics, University of Tehran \\ 2- Assisstant professor in Department of Geomatics, University of Tehran \\ 3- Associate professor in Department of Urbanism, University of Tehran
}

\begin{abstract}
The urban environments may have much functionality in different issues that each one depends on different aspects. This paper presents an analytical framework in spatial database systems for urban layouts to study the relations between urban forms and functionalities of urban environments. The selected functionality that is considered in this paper is Responsiveness of urban environments. The method is based on a precise introduction of the concept in a spatial computational procedure. The presented method makes a comprehensive introduction and consists of parameters and their interactions. The applied method has two main components that are the introduction of responsive environments and the spatial database of urban layouts. The mapping of the parameters and relations to objects and attributes spatial database leads to retrieving the function of responsiveness in spatial database. The method uses many spatial and geometrical parameters to measure the urban layout's components and presents the 16 logical relations between the responsive environments and spatial database components. The implementation is done for district 12, region 4 of the Tehran and the output layers are verified by people's opinions, land use map of extent and field observations.
\end{abstract}

Key words: Spatial database, Urban forms, Responsive environments, Ontology.

Correspondence Address: GIS Division, Department of Surveying and Geomatics, University College of Engineering, University of Tehran, Tehran, Iran. Tel: +98912503 4327

Email: tsilavi @ut.ac.ir 